\title{
Causes of the large warm bias in the Angola-Benguela Frontal Zone in the Norwegian Earth System Model
}

\author{
Shunya Koseki ${ }^{1}$ - Noel Keenlyside ${ }^{1} \cdot$ Teferi Demissie $^{2} \cdot$ Thomas Toniazzo $^{2} \cdot$ \\ Francois Counillon $^{3} \cdot$ Ingo Bethke $^{2} \cdot$ Mehmet Ilicak $^{2} \cdot$ Mao-Lin Shen ${ }^{1}$
}

Received: 5 December 2016 / Accepted: 23 August 2017 / Published online: 14 September 2017

(c) The Author(s) 2017. This article is an open access publication

\begin{abstract}
We have investigated the causes of the sea surface temperature (SST) bias in the Angola-Benguela Frontal Zone (ABFZ) of the southeastern Atlantic Ocean simulated by the Norwegian Earth System Model (NorESM). Similar to other coupled-models, NorESM has a warm SST bias in the ABFZ of up to $8{ }^{\circ} \mathrm{C}$ in the annual mean. Our analysis of NorESM reveals that a cyclonic surface wind bias over the ABFZ drives a locally excessively strong southward $(0.05 \mathrm{~m} / \mathrm{s}$ (relative to observation)) Angola Current displacing the ABFZ southward. A series of uncoupled stand-alone atmosphere and ocean model simulations are performed to investigate the cause of the coupled model bias. The standalone atmosphere model driven with observed SST exhibits a similar cyclonic surface circulation bias; while the standalone ocean model forced with the reanalysis data produces a warm SST in the ABFZ with a magnitude approximately half of that in the coupled NorESM simulation. An additional uncoupled sensitivity experiment shows that the atmospheric model's local negative surface wind curl generates anomalously strong Angola Current at the ocean surface. Consequently, this contributes to the warm SST bias in the ABFZ by $2{ }^{\circ} \mathrm{C}$ (compared to the reanalysis forced
\end{abstract}

Electronic supplementary material The online version of this article (doi:10.1007/s00382-017-3896-2) contains supplementary material, which is available to authorized users.

Shunya Koseki

Shunya.Koseki@gfi.uib.no

1 Geophysical Institute, University of Bergen, Bjerknes Centre for Climate Research, Bergen, Norway

2 Uni Research Climate, Bjerknes Centre for Climate Research, Bergen, Norway

3 Nansen Environmental and Remote Sensing Centre, Bjerknes Centre for Climate Research, Bergen, Norway simulation). There is no evidence that local air-sea feedbacks among wind stress curl, SST, and sea level pressure (SLP) affect the ABFZ SST bias. Turbulent surface heat flux differences between coupled and uncoupled experiments explain the remaining $2{ }^{\circ} \mathrm{C}$ warm SST bias in NorESM. Ocean circulation, upwelling and turbulent heat flux errors all modulate the intensity and the seasonality of the ABFZ errors.

\section{Introduction}

Most state-of-the-art coupled atmosphere-ocean general circulation models (CGCMs) exhibit large warm sea surface temperature (SST) biases in the tropical Atlantic Ocean (e.g., Richter and Xie 2008; Li and Xie 2012; Richter et al. 2012; Toniazzo and Woolnough 2014). The warm SST bias in the eastern equatorial Atlantic is associated with a poor simulation of the observed atmospheric and ocean climatological state (e.g., Richter et al. 2012). In particular, the climatological Inter-tropical Convergence Zone (ITCZ) is shifted southward with erroneously intense rainfall over the equator, surface trade winds and equatorial upwelling are too weak, and the thermocline is too deep in the eastern Atlantic; (e.g., Tozuka et al. 2011; Richter et al. 2014). Studies suggested (e.g., Richter and Xie 2008; Toniazzo and Woolnough 2014) that a westerly wind bias over the western equatorial Atlantic in spring (March-April-May, hereafter MAM) depresses the ocean thermocline in the eastern Atlantic, preventing, the development of an Atlantic cold tongue (ACT, Vizy and Cook 2014) in the Gulf of Guinea in summer (June-July-August, hereafter JJA). Warm SSTs in the Gulf of Guinea can enhance cumulus convection, anchoring the ITCZ over the Gulf of Guinea (e.g., Biasutti et al. 2006) and consequently, suppressing the cross-equator penetration of the western African monsoon (WAM) (e.g., Okumura and 
Xie 2004). The warm biased state in the equatorial Atlantic is then maintained by the Bjerknes feedback (Bjerknes 1969; Keenlyside and Latif 2007; Deppenmeier et al. 2016). A variety of causes have been suggested for the weak simulated Bjerknes feedback including insufficient vertical ocean mixing (Hazeleger and Haarsma 2005), surface freshwater biases (Breugem et al. 2008), insufficient vertical momentum exchange in the atmosphere (Zermeno and Zhang 2013). There is some consensus that the climatological error of the equatorial Atlantic SST arises from weak easterlies associated with dry bias over Amazon (Richter 2015). In fact, the seasonal march of the ITCZ and convective rainfall over the equatorial Atlantic is related closely to the development of the ACT in JJA. There is also an interaction of the West African Monsoonal related surface wind and the ACT is discussed by several previous works (e.g., Okumura and Xie 2004; Tozuka et al. 2011; Druyan and Fulakeza 2014).

The SST errors at the equator are small compared with the warm SST bias along the coast of southwestern Africa where the Angola-Benguela Frontal Zone (ABFZ) forms (e.g., Grodsky et al. 2012; Xu et al. 2014). ABFZ SST biases are among the largest found in state-of-the-art CGCMs, with a model average of $5{ }^{\circ} \mathrm{C}$ and exceeding $8{ }^{\circ} \mathrm{C}$ in some models (IPCC 2013). The ABFZ is the sharp SST gradient region located near $17^{\circ} \mathrm{S}$ at the boundary between the warm southward Angola Current and the cool northward Benguela Current and Benguela upwelling system (e.g., Mohrholz et al. 2004; Colberg and Reason 2006, 2007; Veitch et al. 2006; Goubanova et al. 2013). The ABFZ plays an important role for the local ecosystem (e.g., Auel and Verheye 2007; Chavez and Messié 2009) and weather (Hirst and Hastenrath 1983; Rouault et al. 2003). The origin of the warm bias in the ABFZ is still under discussion. Remote biases over the equator may affect it via the equatorial and coastal waveguide (e.g., Lübbecke et al. 2010). Thermocline perturbations in the west-central equatorial Atlantic propagate as Kelvin Waves eastward and southward along the Equator and then southward along the western African coastline; these outcrop in the ABFZ when they meet the upward sloping isotherms of the Benguela upwelling system (Florenchie et al. 2003). The ABFZ is also sensitive to local winds, in particular, the Benguela low-level coastal jet (e.g., Fennel et al. 2012; Patricola and Chang 2016) and the associated local wind stress curl biases can explain the SST bias (Colberg and Reason 2006; Xu et al. 2014; Grodsky et al. 2012). These local errors were also linked to the South Atlantic Anti-cyclone, and could be enhanced by ocean-atmosphere coupling (Cabos et al. 2016). Richter et al. (2010) also suggest the local impact of surface wind on Benguela Niño events (warm SST anomaly events with inter-annual time scale, e.g., Shannon et al. 1986). Other numerical experiments with CGCMs find a reduction of the SST bias in the $\mathrm{ABFZ}$ with finer vertical and horizontal resolutions of the atmospheric model component (Patricola et al. 2012; Small et al. 2014; Harlaß et al. 2015).

The warm SST biases may also be generated by excessive downward radiative fluxes. The south-eastern Atlantic including the ABFZ is one of regions with frequent lowlevel stratiform cloud formation (e.g., Klein and Hartmann 1993; Pfeifroth et al. 2012; Koshiro and Shiotani 2014). The underestimation of low-level stratocumulus cloud in CGCM can cause the excessive downwelling solar radiation flux over the south eastern Atlantic ocean warming SST (e.g., Huang 2004; Hu et al. 2008, 2010; Wahl et al. 2011). However the stratocumulus feedback is weak in the southeastern Atlantic Ocean in coupled model (Richter 2015), and overall, shortwave radiation erros a minor factor for the warm SST bias in this region (Large and Danabasoglu 2006; $\mathrm{Xu}$ et al. 2014).

The origin of the warm ABFZ bias is less well-understood than the biases at the equator, and there is no consensus on what processes are most important. In this study, we discuss the ABFZ SST bias in the Norwegian Earth System Model, NorESM (Bentsen et al. 2013), and quantify the responsible processes. The rest of this paper is structured as follows. Section 2 details NorESM and its tropical Atlantic SST errors. In Sect. 3 and 4, the different processes responsible for the annual-mean errors are assessed using standalone model experiments. Section 5 describes the role of ocean subsurface errors. In Sect. 6, we will investigate the seasonal evolution of model errors in the ABFZ. The paper concludes with a summary and discussion.

\section{Overviewing of NorESM's systematic biases in the ABFZ}

\subsection{Model and observational data details}

NorESM (Bentsen et al. 2013) is based on the Community Earth System Model verson 1.0.3 (CESM1; Vertenstein et al. 2012). NorESM and, CESM1 share the atmosphere (Community Atmosphere Model version 4.0, CAM4), land (Community Land Model, CLM4), sea ice (Los Alamos Sea Ice Model, CICE4) and coupler components. This study uses the original CAM4 without interactive aerosol representation. The ocean component NorESM-O builds on the the Miami Isopycnic Coordinate Model (MICOM; Bleck et al. 1992). Further details of NorESM are given in Bentsen et al. (2013) and Counillon et al. (2014).

In this study, CAM4 is used with a horizontal resolution $2.5^{\circ}$ in longitude by $1.9^{\circ}$ in latitude, and with 26 vertical hybrid pressure levels ranging from the surface to $3 \mathrm{hPa}$. MICOM is configured on a tri-polar horizontal grid with approximately uniform spacing of $2.0^{\circ}$ in longitude and a variable spacing in latitude between $2.0^{\circ}$ in mid-latitude and 
$1 / 2^{\circ}$ at the equator (and about $1.0^{\circ}$ around the ABFZ); in the vertical it comprises a stack of 51 isopycnic layers with two additional layers to represent the bulk mixed layer on top. The coupled model was initialized with data from the Polar Hydrographic Climatology version 3.0 (PHC 3.0, Steele et al. 2001). Spin-up of this coupled model is for 1500 years using constant preindustrial external forcing. Consequently, the model was integrated with historical forcings from 1 January 1850 to 31 December 2004. In the following we analyse the monthly-mean model output for the period 1980 to 2004.

Model performance is assessed by comparing against the observational data of Hadley Centre Sea Ice and Sea Surface Temperature data set (HADISST) version 2 (e.g., Tichner and Ravner 2014) for SST from 1980 to 2004 and against Archiving Validation, Interpretation of Satellites Oceanographic (AVISO, http://www.aviso.oceanobs.com/duacs/) data from 1993 to 2001 for sea surface height (SSH) and World Ocean Atlas 13 (WOA13, Locarnini et al. 2013) for subsurface sea water temperature from 1980 to 2004. For the surface atmospheric quantities, we compare against Common Ocean-ice Reference Experiments version 2 interannual forcing (COREv2-IAF) data (Large and Yeager 2008), which is based on the National Centers for Environmental Prediction (NCEP) and National Center for Atmospheric Research (NCAR) reanalysis. We have chosen the CORE product because it allows a clearer comparison with the stand-alone ocean model runs; use of ERA-Intrim does not change any of the major conclusions in terms of NorESM biases. None of our analysis time periods considers data prior to the satellite period.

\subsection{NorESM tropical Atlantic SST Biases}

In this section, we summarise the performance of NorESM in simulating the observed annual mean tropical Atlantic climate (Fig. 1). All of biases shown in this study are estimated according to the following formula,

$B I A S=\overline{A_{m}}-\overline{A_{o}}$,

where, $A$ is the quantity considered, subscripts of $m$ and $o$ denote model and observation, and overbar is the annualmean climatology for model's integrated years. The equatorial warm SST bias is most intense in boreal summer (JJA, not shown) during the West Africa Monsoon season. The timing is consistent with previous studies (e.g., Richter 2015) that show the errors in this month result from the amplification of wind errors in boreal spring by the Bjerknes feedback. Similar to other CGCMs (e.g., Richter et al. 2012), NorESM has a large warm SST bias in the eastern tropical Atlantic that reaches $4{ }^{\circ} \mathrm{C}$ at the equator and $8{ }^{\circ} \mathrm{C}$ off the southwestern African coast. By contrast, cool biases are detected in the southern and northern subtropical Atlantic
Ocean. In the southeast Atlantic, the simulated ABFZ is located too far south at $24^{\circ} \mathrm{S}$ (the observed ABFZ is around $15-17^{\circ} \mathrm{S}$ ), reflecting the large warm bias. These biases in the ABFZ show the relatively modest seasonality although the bias is largest in JJA (Sect. 6). This study focuses on the $\mathrm{ABFZ}$ defined as the region from $10^{\circ} \mathrm{E}$ to the coast and between $10^{\circ} \mathrm{S}-20^{\circ} \mathrm{S}$; the region is marked on Fig. 1a.

In observations, $\mathrm{SSH}$ is higher to the west than in the east in the tropical southern Atlantic. The lowest in SSH is around the ABFZ and reaches the southwestern African coast. The high in SSH in the southwestern Atlantic is at the centre of the subtropical gyre with the Brazil Current at its western side (e.g., Bilo et al. 2014). In NorESM, however, the lowest SSH in the ABFZ seems to be displaced southward because the SSH bias is negative south of the ABFZ and positive north of it. The low SSH bias is largest in the Benguela upwelling region and this error extends northwestward, and as a result of which the centre of the low SSH detaches from the coast south of the observed position. On the other hand, a high (low) SSH bias is induced in the eastern (western) equatorial Atlantic. This bias reflects the deepening of thermocline in the eastern equatorial Atlantic and consequently warmer SST, and is associated with too weak easterly (Richter and Xie 2008; Ding et al. 2015).

This SSH bias induces the surface geostrophic current bias (estimated by, $\left(u_{g}, v_{g}\right)=\frac{g}{f}\left(\frac{\partial S S H}{\partial y}, \frac{\partial S S H}{\partial x}\right)$, where the subscript denotes the surface geostrophic component) as well. In observations, the (warm) southward Angola Current and the (cold) northward Benguela Current meet around $15^{\circ} \mathrm{S}$ and $10^{\circ} \mathrm{E}$ to form the ABFZ. NorESM simulates a stronger southward Angola Current and a weaker northward Benguela Current, and the ABFZ is situated erroneously $24^{\circ} \mathrm{S}$. Thus, warm tropical water intrudes further southward and the equatorward penetration of cool extratropical water is prevented. This situation is analogous to a Benguela Niño anomaly (e.g., Shannon et al. 1986) and the southward intrusion of the Angola Current shifts the ABFZ far southward. Section 4.2 gives a detailed vertical structure of the ocean current around the ABFZ.

The model biases in the ocean are associated with the atmospheric biases (Fig. 2). The observational annual-mean rainfall shows intense rainfall rate over the equatorial Atlantic, the African Continent, and the Amazon in the annual mean. NorESM has a large wet bias over the southern equatorial Atlantic and the African Continent and a large dry bias over the northern equatorial Atlantic and Amazon. These remarkably large errors are in common with other CGCMSs (e.g., Richter et al. 2012). In particular, the raninfall bias over the equator is strongly linked to the underlying warm SST bias. The warm SST bias anchors the ITCZ to the equator and consequently the Western African Monsoon does not penetrate far enough northward (e.g., Okumura and Xie 

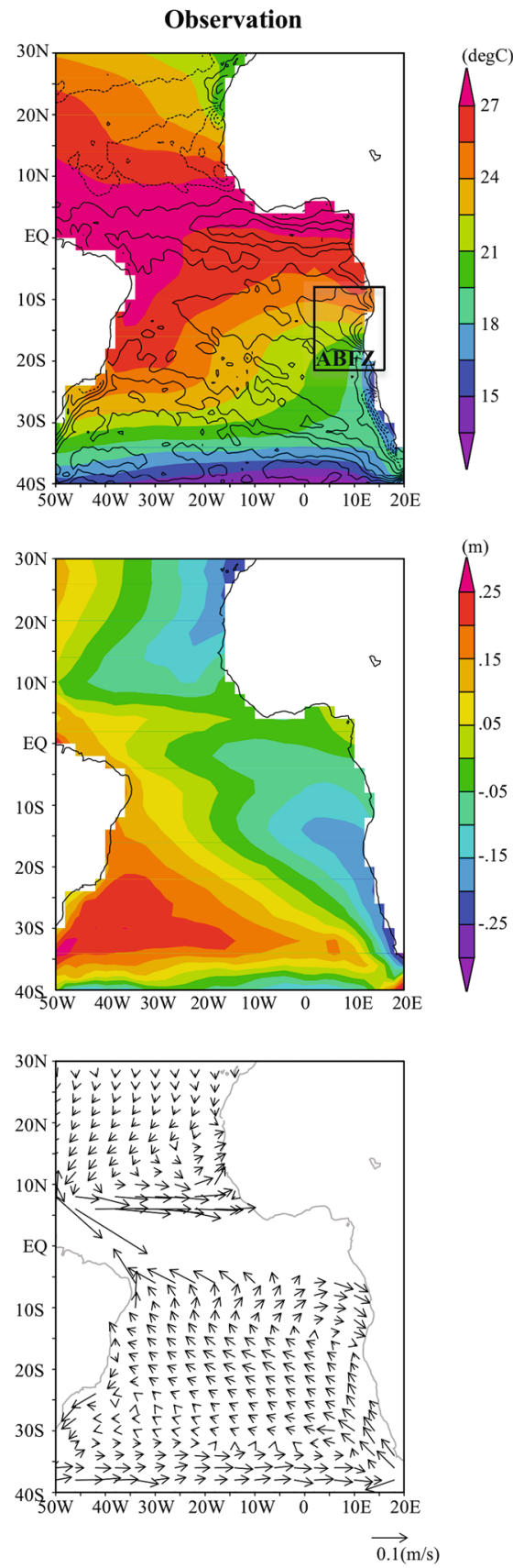

Fig. 1 (Left) The observed climatological annual mean and (right) the corresponding NorESM biases are shown for (1st row) SST (shaded) and its meridional gradient (contour), (2nd row) sea level height (SSH) anomaly from domain-mean $\left(30^{\circ} \mathrm{S}-30^{\circ} \mathrm{N}\right.$ and $\left.50^{\circ} \mathrm{E}-20^{\circ} \mathrm{E}\right)$, and $(3 \mathrm{rd}-$ row) geostrophic current estimated from $\mathrm{SSH}$. Contour interval of

2004). The coastal wet bias in south west Africa may be also caused by the warm bias in the ABFZ (e.g., Nicholson and Entekhabi 1987; Rouault et al. 2003).

The Southern Atlantic Anticyclone (SAA, e.g., Miyasaka and Nakamura 2010) is the.
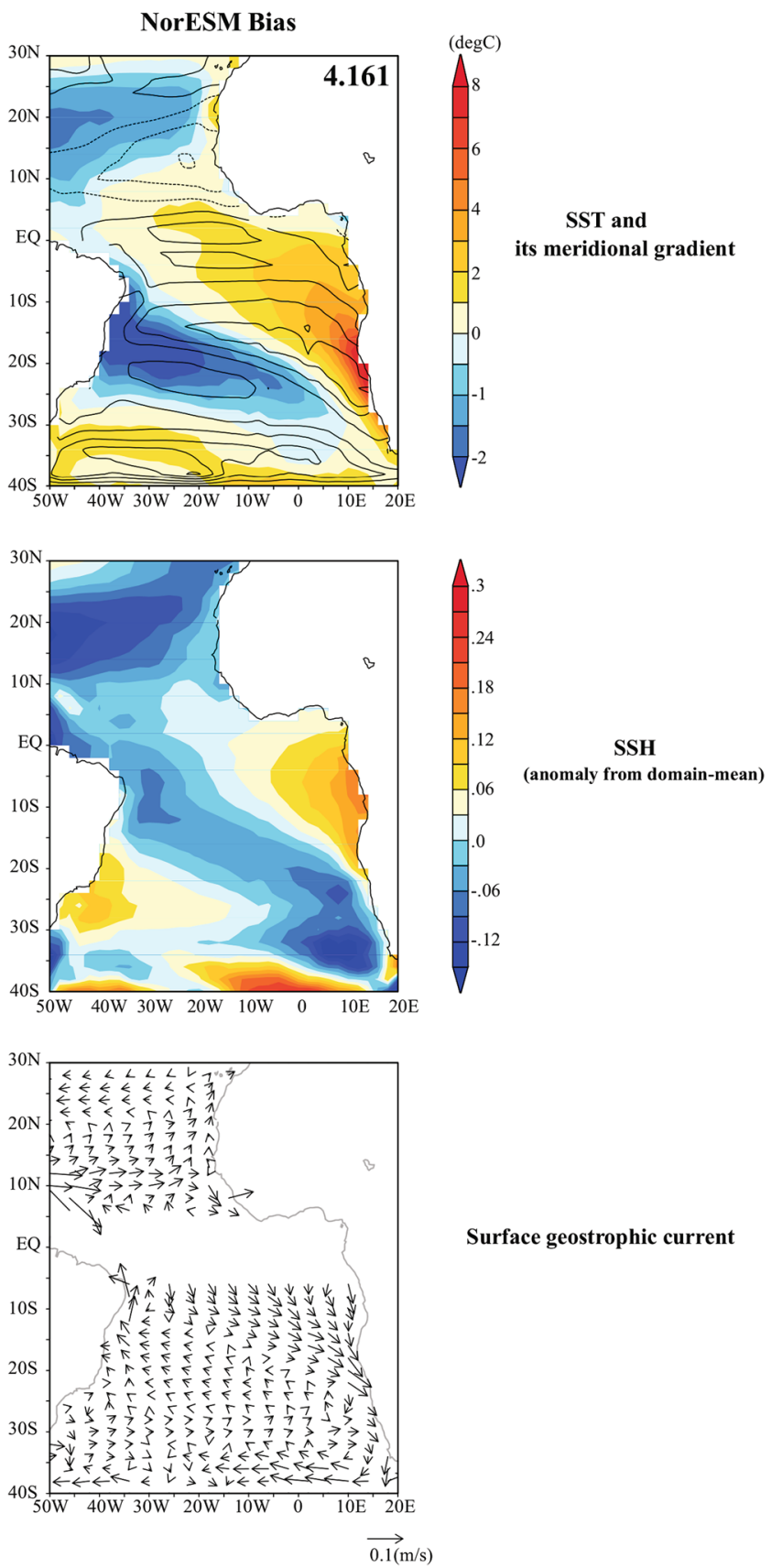

Surface geostrophic current

the meridional SST gradient is $0.2{ }^{\circ} \mathrm{C} /{ }^{\circ}$. SST meridional gradient in NorESM is not a bias from observation, but its exact value. For the observation, HadISST and AVISO are used for SST and SSH for 1980-2004 and 1993-2000, respectively. The RMSE of SST bias of NorESM $\left(25^{\circ} \mathrm{S}-10^{\circ} \mathrm{S}\right.$ and $\left.0^{\circ}-15^{\circ} \mathrm{E}\right)$ is listed on top-right of the figure

dominant feature of the subtropical south Atlantic atmospheric circulation. It is associated with an intense southerly low-level jet that blows along the western African coast and enhances the Benguela upwelling (e.g., Goubanova et al. 2013; Junker et al. 2015; Cabos et al. 2016). The SAA is linked to both equatorial and southeastern 

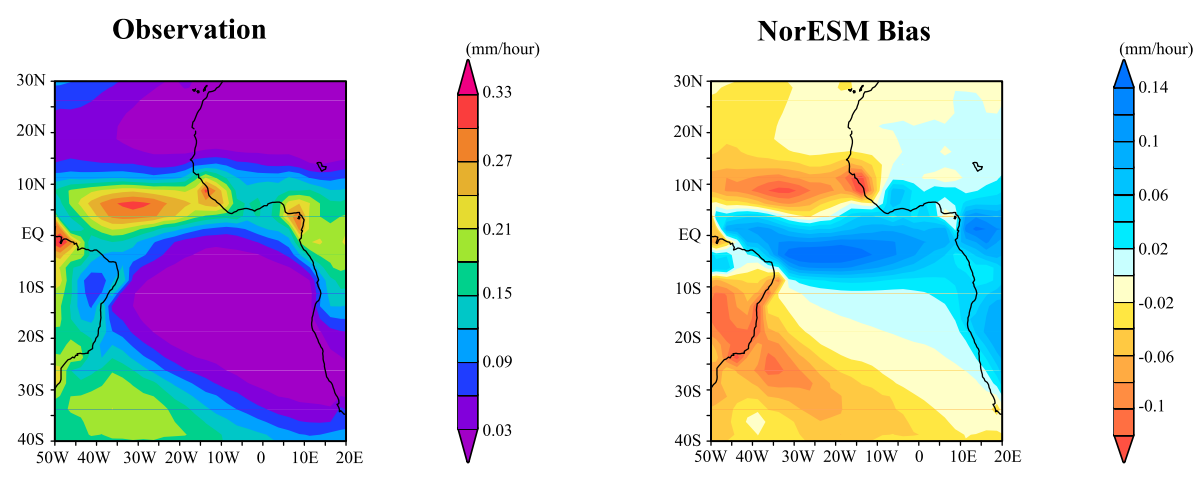

Rainfall
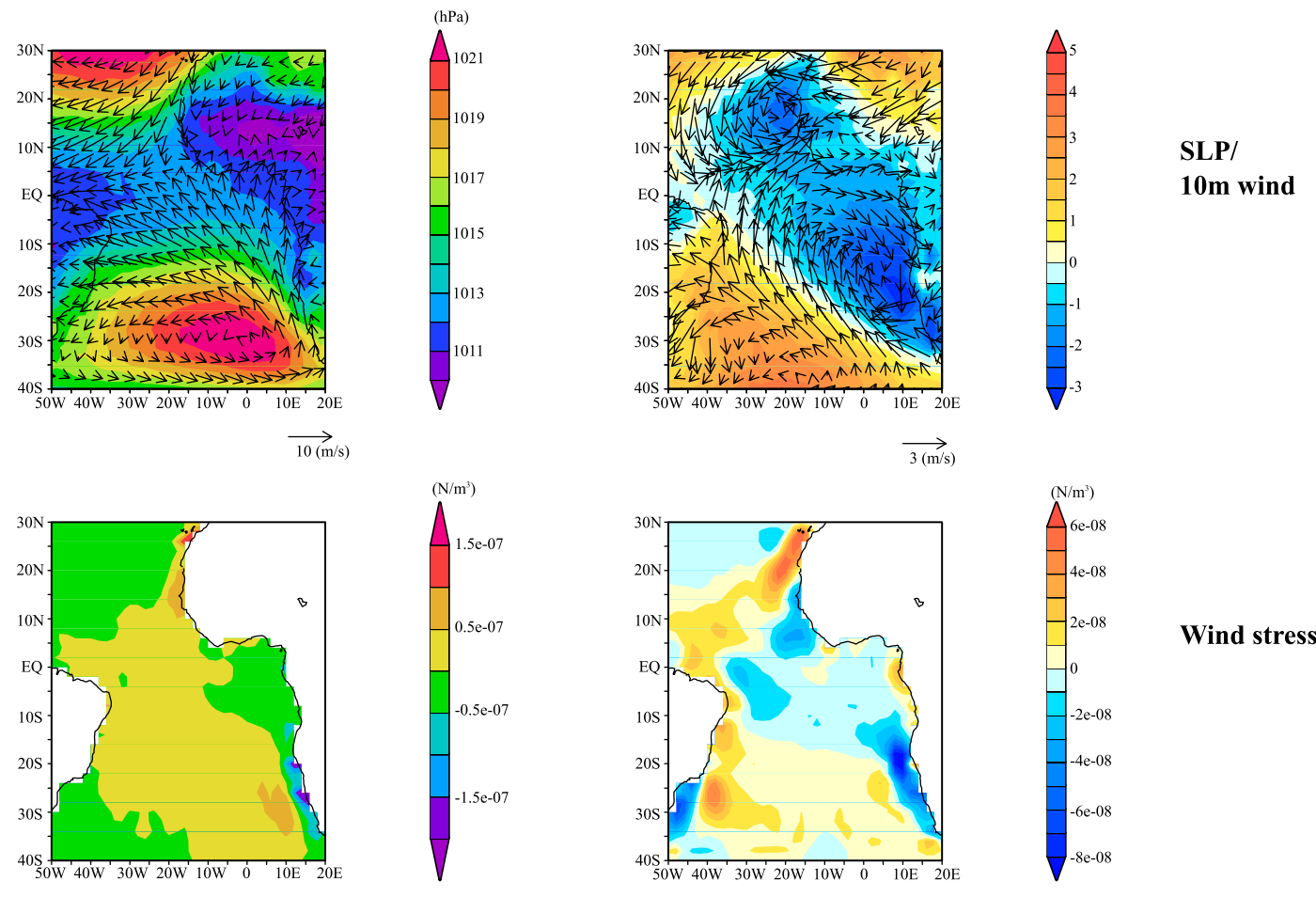

\section{Wind stress curl}

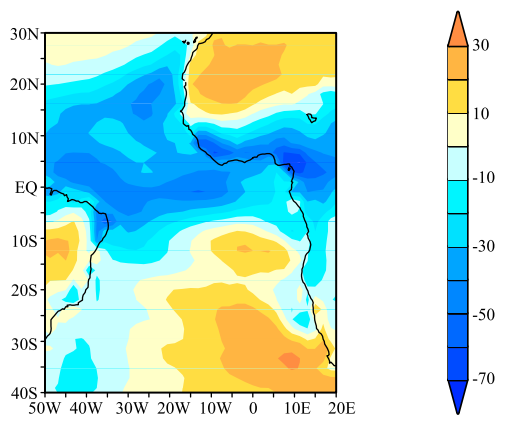

Downward
shortwave radiation
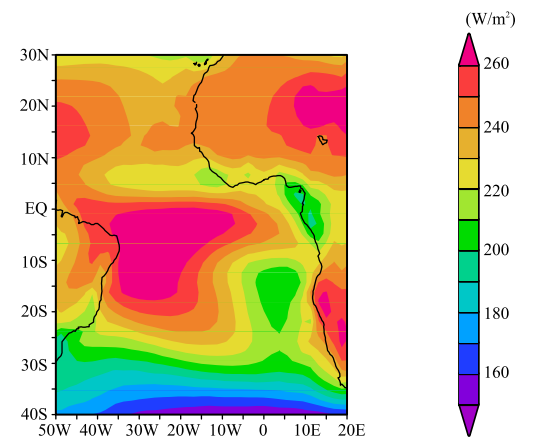

Fig. 2 (Left) the observed climatological annual-mean and (right) the corresponding NorESM biases are shown for (1st row) rainfall, (2nd row) sea level pressure (SLP, shaded) and $10 \mathrm{~m}$ wind (vectors), (3rd row) wind stress curl over the ocean, and (4th row) downward shortwave radiation at the surface. For the observations, we employ GPCP for rainfall and CORE Interannual Forcing Version2 (COREIAFv2) for SLP, $10 \mathrm{~m}$ wind, wind stress curl and downward shortwave radiation for 1980-2004 
Atlantic variability (Lübbecke et al. 2010; Nnamchi et al. 2015).

NorESM has biases in SLP and surface wind. Over the equatorial Atlantic there is westerly bias, which is linked to the equatorial warm SST bias. The SAA in NorESM is distorted and shifted southwestward, and there is a low-pressure bias in SLP over the eastern subtropical Atlantic, centred over the ABFZ. The low-pressure bias creates a clockwise atmospheric circulation bias, with a northerly wind bias along the African coast that weakens wind-driven upwelling along the Benguela coast. The cyclonic wind-stress curl bias in the ABFZ is also of key importance: the observed cyclonic wind stress curl along the Angola/Benguela coast drives Ekman pumping, surface current divergence, the SSH low, cyclonic oceanic surface circulation and the generation of the ABFZ (e.g., Colberg and Reason 2006) (Note the observational wind stress here is estimated using bulk formula in a standalone ocean model simulation forced by COREv2-IAF; see Sect. 3). In NorESM the negative wind stress curl is enhanced compared to the observations and the minimum shifts offshore in the ABFZ. This negative wind stress curl bias causes the offshore minimum of $\mathrm{SSH}$, and the corresponding far southward intrusion of the Angola Current in the ABFZ. Additionally, we compared the NorESMmodelled wind stress curl with the ERA-Interim reanalysis data (Dee et al. 2011). The NorESM bias is approximately identical around the ABFZ (not shown).

NorESM has also large errors in shortwave radiation over the tropical Atlantic. In observations, the downward shortwave radiation over the $\mathrm{ABFZ}$ is relatively low compared to other regions of the southern Atlantic. This is because of the attenuation of incoming solar radiation due to low-level stratocumulus cloud (e.g., Klein and Hartmann 1993). NorESM shows the positive radiation bias around the ABFZ and over the south Atlantic. As other CGCMs, NorESM seems to fail to reproduce the low-level stratocumulus over the Southern Atlantic (e.g., Mechoso et al. 2016). The positive shortwave radiation bias is the largest over the ABFZ in JJA $(70 \mathrm{~W} /$ $\mathrm{m}^{2}$, not shown). The annual-mean error, however, is much smaller around the ABFZ $\left( \pm 10 \mathrm{~W} / \mathrm{m}^{2}\right)$. Negative shortwave radiation biases are seen over the equatorial Atlantic and the coastal region of the Gulf of Guinea. More frequent cumulus and anvil clouds and associated with the positive rainfall bias may cause this.

\section{Experimental designs of standalone experiments of atmosphere and ocean}

In the previous section, the warm SST bias in the ABFZ was related to local errors in the atmosphere and the ocean. Here, sensitivity experiments are conducted with the atmosphere (CAM4) and ocean (MICOM) model components of NorESM separately, to quantitatively elucidate the causes of the warm SST bias. The configuration of these components in the stand-alone simulations is identical to that used NorESM. Table 1 summarises the experiments.

We first estimate the intrinsic ocean and atmosphere model errors through performing control experiments with the separate model components forced by observational based products. The atmospheric model control experiment (A-CTL) follows the AMIP5 protocol (Taylor et al. 2012), and is forced by National Oceanic and Atmospheric Administration (NOAA) Optimum Interpolation SST (OISST, Reynolds et al. 2002) daily data. The integration runs from 1982 to 2001, and the first year is considered spin-up and not analysed. The ocean model control experiment (O-CTL) is forced by COREv2-Interannual forcing (COREv2-IAF, Large and Yeager 2008) from 1948 to 2007. To spin-up the ocean model, we perform 5 cycles running from 1948 to 2007 without any surface relaxation; we analyze the sixth cycle of the integration from 1980 to 2004 for O-CTL. Note that other sensitivity experiments as mentioned below restart at 1980 in 6th cycle of O-CTL spin-up.

Second, we conduct two sensitivity experiments with MICOM and CAM4 to investigate how the local clockwise wind stress curl bias impacts ocean current and SST in the ABFZ and to assess the role of coupled feedbacks in

Table 1 Setting details of each standalone experiments

\begin{tabular}{|c|c|c|c|c|c|}
\hline Experiment & Type & Forcing & Integration period & Blending Forcing & Blending Area \\
\hline A-CTL & Control & OISST & 1983-2001 & None & None \\
\hline $\mathrm{O}-\mathrm{CTL}$ & Control & COREv2 & 1980-2004 & None & None \\
\hline $\mathrm{O}-A-C T L$-Wind & Sensitivity & COREv2 & 1980-2004 & $10 \mathrm{~m}$ wind $(\mathrm{A}-\mathrm{CTL})$ & $\mathrm{ABFZ}$ \\
\hline A-O-A-CTL-Wind-SST & Sensitivity & OISST & 1983-2001 & $\operatorname{SST}(\mathrm{O}-A-C T L-\mathrm{Wind})$ & ABFZ \\
\hline O-NorESM-TA_Wind & Sensitivity & COREv2 & 1980-2004 & $10 \mathrm{~m}$ wind (NorESM) & Tropical Atlantic \\
\hline O-NorESM-TA_WindHeat & Sensitivity & COREv2 & 1980-2004 & $\begin{array}{l}10 \mathrm{~m} \text { wind (NorESM), T/Q } \\
\text { anomaly (NorESM-A-CTL) }\end{array}$ & Tropical Atlantic \\
\hline O-NorESM-TA_All & Sensitivity & COREv2 & 1980-2004 & $\begin{array}{l}10 \mathrm{~m} \text { wind (NorESM), T/Q } \\
\text { anomaly (NorESM-A-CTL) } \\
\text { shortwave radiation (NorESM) }\end{array}$ & Tropical Atlantic \\
\hline
\end{tabular}


amplifying these errors. Specifically, we force the individual models with a blend of data from the observed climatology and of data simulated by the other model component over the ABFZ (Fig. 13). The blending methodology is detailed in Appendix A1. The series of experiments are (1) O-A$C T L$-Wind, MICOM forced by locally-blended $10 \mathrm{~m}$ wind from A-CTL over the ABFZ; (2) A-O-A-CTL-Wind-SST, CAM4 forced by locally-blended SST from O-A-CTL-Wind over the ABFZ; Thus, the chain of experiments assesses the local ocean-atmosphere interaction in errors in the ABFZ, and can lead us to understand dynamical causes for the warm SST bias in the ABFZ in a local scale.

Finally, we conduct three more sensitivity experiments to examine the impact of NorESM heat flux and remote equatorial errors on the SST in the ABFZ. In these experiments, the climatological blending is employed over the entire southern-tropical Atlantic Ocean $\left(30^{\circ} \mathrm{S}-5^{\circ} \mathrm{N}\right.$, see Appendix A2 and Fig. 14). Three experiments are performed: (1) O-NorESM-TA_Wind, MICOM is forced by blended $10 \mathrm{~m}$ wind from NorESM to estimate the impact of (remote and local) coupled model wind errors. (2) O-NorESM-TA_WindHeat, is identical to O-NorESM-TA_Wind except that temperature and specific humidity errors of NorESM are added to the COREv2-IAF forcing (Appendix A2) to estimate the additional contribution of surface turbulent heat flux errors on the SST bias. (3) O-NorESM-TA_All, as O-NorESM-TA_ WindHeat except that shortwave radiation from NorESM is added to assess the additional impact of the coupled model shortwave radiation errors on SST. All of sensitivity experiments cover at least the period 1982-2004. Through them we attempt to reconstruct the full SST bias of NorESM and quantify the contribution of each process.

\section{Annual-mean biases arising in standalone experiments}

\subsection{Control runs}

Here we assess errors intrinsic to the ocean and atmosphere components of NorESM trough standalone control simulations forced with observational based products (O-CTL, A-CTL). The CAM4 control shows significant climatological errors in $10 \mathrm{~m}$ horizontal wind and SLP (Fig. 3). There are local clockwise $10 \mathrm{~m}$ horizontal wind errors over the ABFZ and an anticlockwise circulation error dominates over the south-west Atlantic that is quite similar to those of NorESM (Fig. 2). Thus, the NorESM errors in this region appear intrinsic to the atmospheric model CAM4. By contrast the errors at the equator appear enhanced by ocean-atmosphere interaction. In particular, a westerly wind bias over the western equatorial Atlantic in MAM $\left(40^{\circ} \mathrm{W}-20^{\circ} \mathrm{W}\right)$ that is found in both uncoupled and coupled

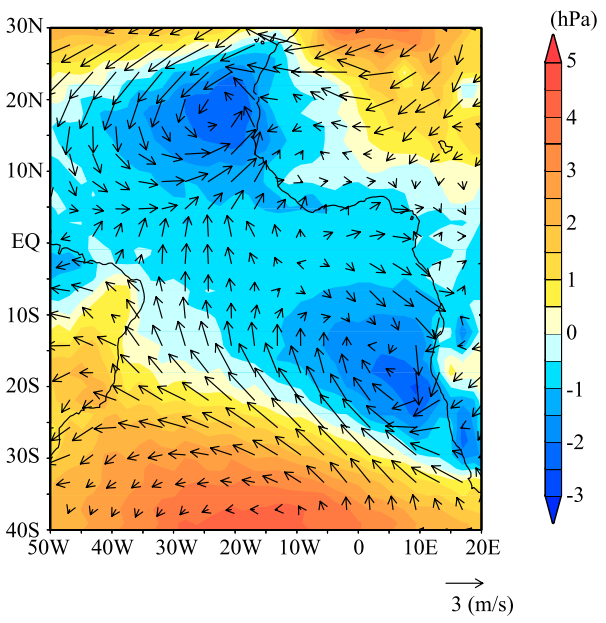

Fig. 3 Annual-mean biases of CAM4 control experiment (A-CTL) for SLP (shaded) and $10 \mathrm{~m}$ wind (vectors) with respect to COREIAFv2 for 1982-2001

simulations, is strongly enhanced in JJA in the coupled simulation. As a result, in the annual mean the westerly bias over the equator in the coupled model (Fig. 3) is much larger than that in uncoupled model (Fig. 2). This is consistent with previous literature (e.g., Richter et al. 2012).

O-CTL has a warm SST bias in the southeastern Atlantic that is about a half of NorESM's warm bias (Fig. 4a). In particular, south of $20^{\circ} \mathrm{S}$ along the Benguela coast the SST bias is around $4{ }^{\circ} \mathrm{C}$. In O-CTL the ABFZ is located at around $18^{\circ} \mathrm{S}$, and this is more realistic than in NorESM (Fig. 4a). Although SSH in O-CTL is still too low (about $-0.09 \mathrm{~m}$ ) in the southeastern Atlantic coastal region, the SSH and corresponding surface geostrophic current errors around the ABFZ are reduced compared to NorESM (Fig. 4b, c). The COREv2-IAF data have a resolution of about $2^{\circ}$. Although a finer horizontal and vertical atmospheric model resolution might reduce the ABFZ bias (Harlaß et al. 2015), even at a quarter degree resolution MICOM forced with COREv2-IAF exhibits a similar warm SST bias (in Fig. S1). This is possibly because the COREv2-IAF does not resolve the local low-level jet over the ABFZ, which is crucial for generating the ABFZ (e.g., Colberg and Reason 2006; Patricola and Chang 2016).

\subsection{Locally blended experiments}

The previous subsection showed that both atmosphere and ocean model components separately produce large local biases when driven with realistic forcing. In this section, we perform sensitivity experiments to investigate whether and how these intrinsic local errors enhance each other.

To quantify the impact of the CAM4 intrinsic wind errors over the ABFZ, we perform an ocean model 


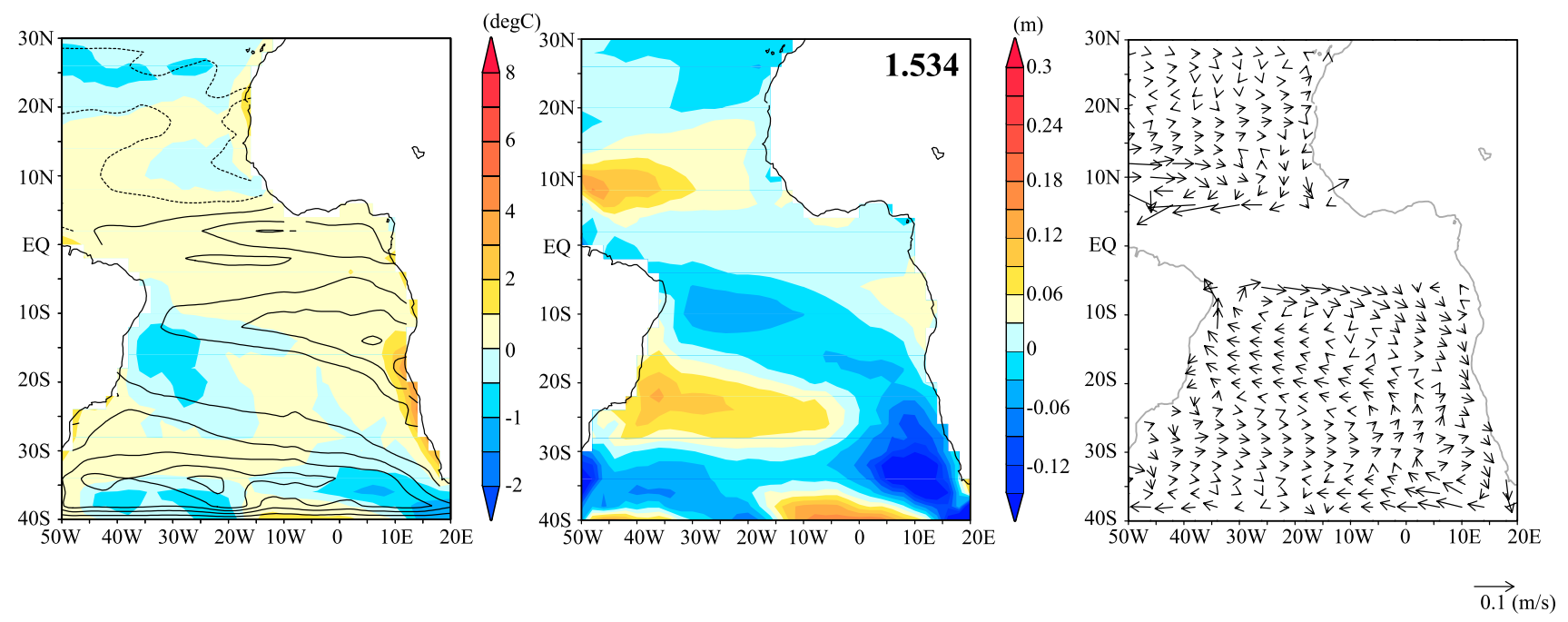

Fig. 4 Annual-mean biases of MICOM control experiment (O-CTL) for (left) SST (shaded), (middle) SSH deviations from domain-mean (as in Fig. 1), and (right) surface geostrophic current estimated from $\mathrm{SSH}$. Contours on the left figure show the meridional gradient of SST

experiment (O-A-CTL-Wind) that is identical to O-CTL except that the A-CTL climatological winds are now blended in over the ABFZ region. The experiment shows that CAM4 intrinsic cyclonic wind stress errors over the $\mathrm{ABFZ}$ region enhance the SST bias by about $2{ }^{\circ} \mathrm{C}$ in this region compared to the MICOM control (Fig. 5a). This enhanced warming is linked to a southward displacement of the ABFZ to around $21^{\circ} \mathrm{S}$, which is roughly the location of the ABFZ in NorESM (Fig. 1). This indicates that the intrinsic CAM4 local surface wind error is the main cause for the erroneous southward shift of the ABFZ in NorESM.

The enhanced warm bias and southward shift of the ABFZ in O-A-CTL-Wind can be explained by the geostrophic current associated with these SSH errors. In O-A$C T L$-Wind, the lower SSH around the ABFZ is enhanced, increasing the SSH gradient around the ABFZ (Fig. 5b). This intensifies the Angola Current and causes it to penetrate further south compared to O-CTL, and weakens the northward Benguela Current (bias of southward current along the west African coast (south of $20^{\circ} \mathrm{S}$ ) shown in Fig. 5c). These local circulation errors in $\mathrm{O}-\mathrm{A}-\mathrm{CTL}$-Wind are quite similar to those in NorESM: RMSEs of meridional geostrophic current in NorESM and O- $A$ - $C T L$-Wind with respect to AVISO are 0.026 and $0.0310 \mathrm{~m} / \mathrm{s}$, while for O-CTL the RMSE is $0.012 \mathrm{~m} / \mathrm{s}$. Consistently, the intrinsic CAM4 negative wind stress curl errors in the ABFZ (Fig. 5d) are almost identical to those in NorESM (Fig. 1). Despite these ocean circulation similarities, other processes appear to contribute as the warm SST bias in O-A-CTL-Wind is less than that in NorESM. in O-CTL. The observations used for the evaluation are the same as Fig. 1. The RMSE of SST bias of O-CTL $\left(25^{\circ} \mathrm{S}-10^{\circ} \mathrm{S} ; 0-15^{\circ} \mathrm{E}\right)$ is listed in the middle panel

The representation of the vertical structure of the Angola Current may contribute to the warm SST bias and to differences among experiments. A through assessment of the simulation is, however, not possible, because of the scarcity of ocean current observations. Thus, we can only make a rough comparison of the vertical profile of meridional current velocity at $11^{\circ} \mathrm{S}$ and $13^{\circ} \mathrm{E}$ (Fig. 6) with the $\sim 2$ years of observations from a single mooring at the same location (Fig. 9 in Kopte et al. 2017). Although O-CTL, O-A-CTLWind and NorESM indicate an Angola Current, compared to the in situ observations, all three underestimate the southward current (this is not unexpected given we comparing a $\sim 2^{\circ}$ grid cell with a point measurement). While O-CTL has a peak of southward current around $50 \mathrm{~m}$ depth, which is approximately consistent with the observations, NorESM and $\mathrm{O}-A-C T L-W i n d$ have much shallower southward current at around 20-30 m depth. These profiles seem to be similar to those of reanalyses shown by Kopte et al. (2017), and show that our model has a basic representation of the vertical structure of the Angola Current. We further consider vertical-longitude sections of meridional current velocity at $15^{\circ} \mathrm{S}$, just north to the observed ABFZ. All three experiments have core of southward current at $50 \mathrm{~m}$ depth (Fig. 6b-d). The surface southward current in NorESM and $\mathrm{O}-A-C T L$-Wind is much stronger than that in O-CTL. Additionally, there is weak equatorward surface current offshore (east of $10^{\circ} \mathrm{E}$ ) in O-CTL that is not reproduced by NorESM and $\mathrm{O}-A-C T L$-Wind. This further supports the impact of the local wind stress curl bias in NOrESM on the overestimation of the southward Angola Current, consistent with our analysis of surface geostrophic current. 
(a) SST and its meridional gradient
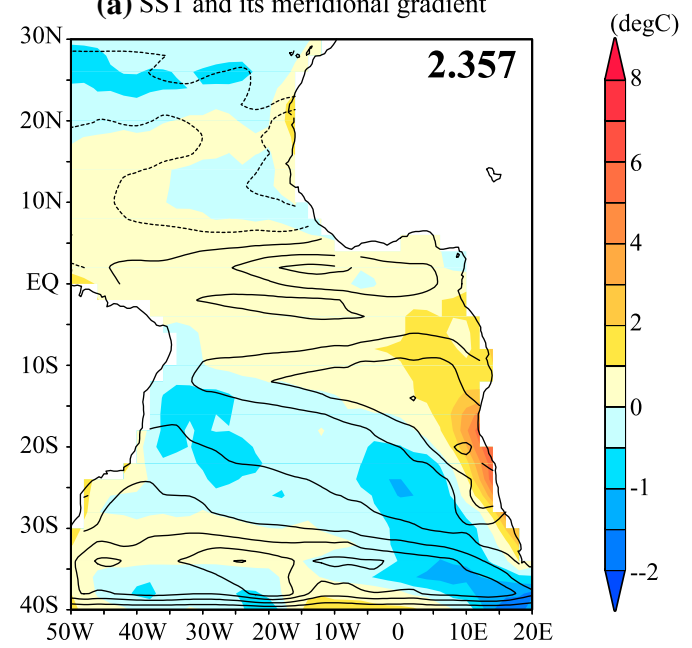

(c) Surface geostrophic current

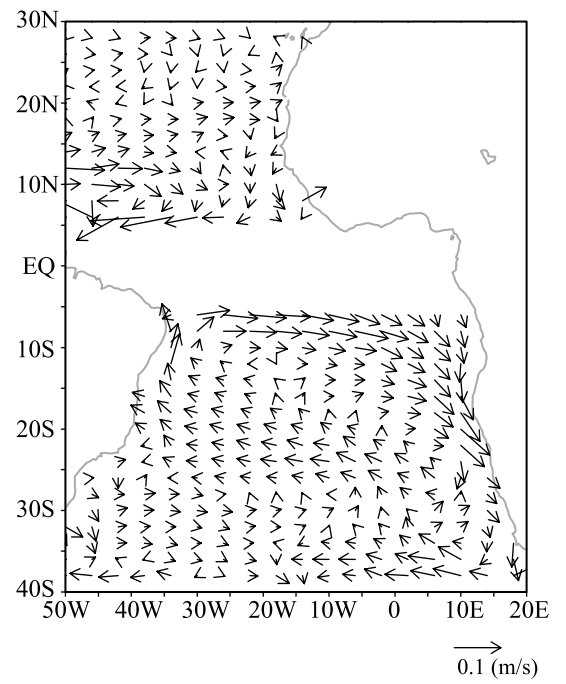

Fig. 5 Annual-mean biases of MICOM sensitivity experiment (O-A-CTL-Wind) for a SST, b SSH deviations from the domain-mean value (as in Fig. 1), c surface geostrophic current estimated from SSH, and d wind stress curl.

To assess whether ocean-atmosphere interaction can further enhance the errors in the ABFZ we perform a CAM4 experiment (A-O-A-CTL-Wind-SST) that is identical to A-CTL, except that SST from O-A-CTL-Wind is blended locally with the observational SST. There is a local additional impact of the warm SST bias in the ABFZ on the intrinsic atmosphere (Fig. 7). The local SST biases enhance the SLP error $b$ about a quarter $(0.45 \mathrm{hPa})$ compared with the stand-alone intrinsic CAM4 SLP error (see Fig. 2). However, the spatial-scale is relatively small compared to the intrinsic bias of CAM4, and SLP is lowered significantly only over the ABFZ where SST bias is (b) SSH departed from domain-mean

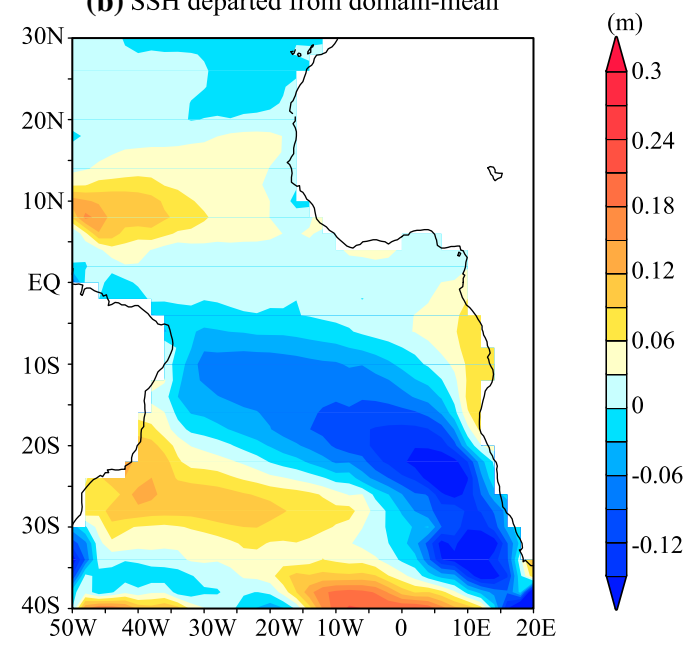

(d) Wind stress curl

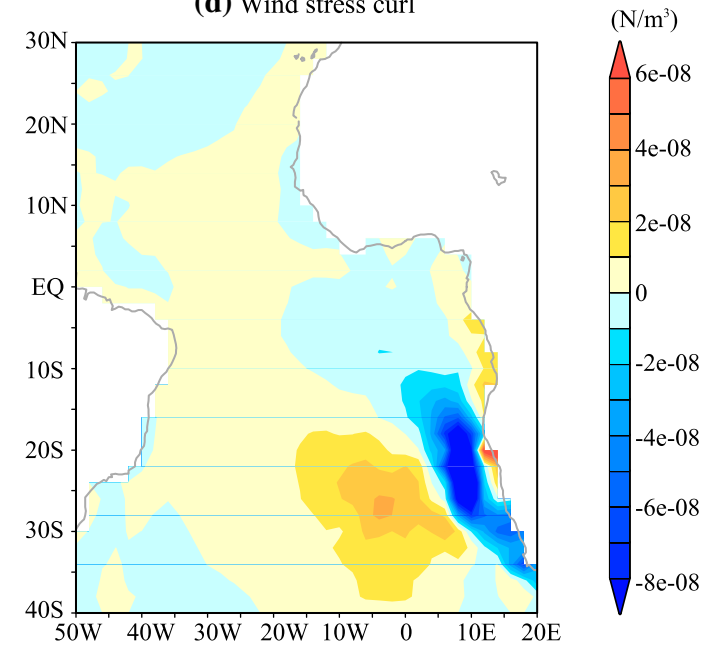

The contour on (a) denotes the SST meridional gradient (CI, $0.2^{\circ} \%^{\circ}$ ). The observations used for the evaluation are the same as Fig. 1. The RMSE of SST bias of O-CTL $\left(25^{\circ} \mathrm{S}-10^{\circ} \mathrm{S} ; 0-15^{\circ} \mathrm{E}\right)$ is listed in the top-left figure

added. The $10 \mathrm{~m}$-wind errors do not appear to be strongly amplified over the ABFZ and in particular, the cyclonic circulation error is not strengthened; instead, a weak convergent flow forms over the ABFZ $\left(10^{\circ} \mathrm{E}\right.$ and $\left.10^{\circ} \mathrm{S}-20^{\circ} \mathrm{S}\right)$. As a consequence, adding these wind errors to the O- $A$ $C T L$-Wind forcing over the ABFZ region does not further enhance the warm SST bias in another experiment (not shown). Thus, we do not find evidence for local feedback among SST, SLP, winds, and ocean-current biases in the ABFZ; three quarters of the NorESM warm SST bias in this region can be understood in terms of local biases that are generated by the intrinsic dynamics of the ocean and 

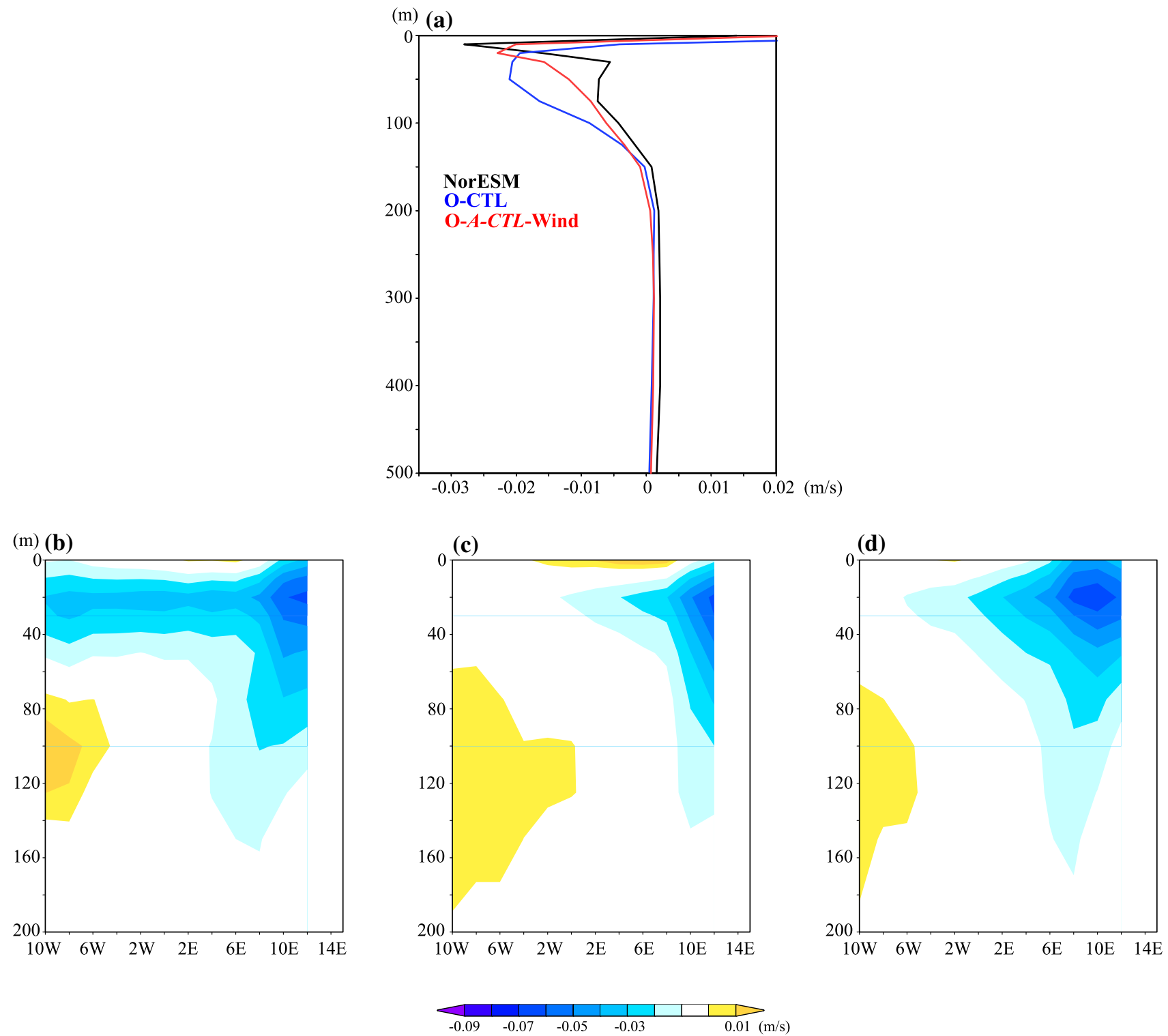

Fig. 6 a A vertical profile of annual-mean climatological meridional ocean current at $11^{\circ} \mathrm{S}$ and $13^{\circ} \mathrm{E}$ for (black) NorESM, (blue) O-CTL, and (red) O-A-CTL-Wind. b-d Vertical-longitude sections of annual-

atmosphere models in forced mode, separately and independently of each other.

\subsection{Whole-tropical/southern Atlantic blended experiments}

We have quantified that intrinsic ocean model errors and intrinsic atmospheric model wind stress curl errors contribute to about $75 \%$ of the warm SST bias in the ABFZ in NorESM. In this subsection, further experiments quantify the contributions of remote wind forcing, shortwave radiation, and turbulent surface heat fluxes to the remaining ABFZ SST bias (Appendices A1, A2). In uncoupled ocean mean climatological meridional ocean current at $15^{\circ} \mathrm{S}$ for NorESM, $\mathrm{O}-\mathrm{CTL}$, and O-A-CTL-Wind, respectively

model experiments SST is restored to the atmospheric thermodynamic forcing, because surface turbulent heat fluxes are computed with bulk formula that use $2 \mathrm{~m}$ temperature and specific humidity. Thus, the contribution of turbulent heat fluxes requires special attention when diagnosing coupled model errors using uncoupled model experiments.

To quantify the impact of remote wind errors on the ABFZ SST bias we perform an experiment (O-NorESMTA_Wind) identical to O-CTL except that climatological NorESM winds are blended over the entire tropical Atlantic. Considering the NorESM wind errors over the entire tropical and South Atlantic leads to a somewhat warmer SST bias in the equatorial Atlantic compared to the MICOM control 
Fig. 7 Climatological difference of annual-mean between CAM4 sensitivity experiment (A-O-A-CTL-Wind-SST) and control experiment (A-CTL) for sea level pressure (shaded) and $10 \mathrm{~m}$ wind (vectors). The white thick contour denotes SLP differences significant at the $95 \%$ level according to the Student's $t$ test

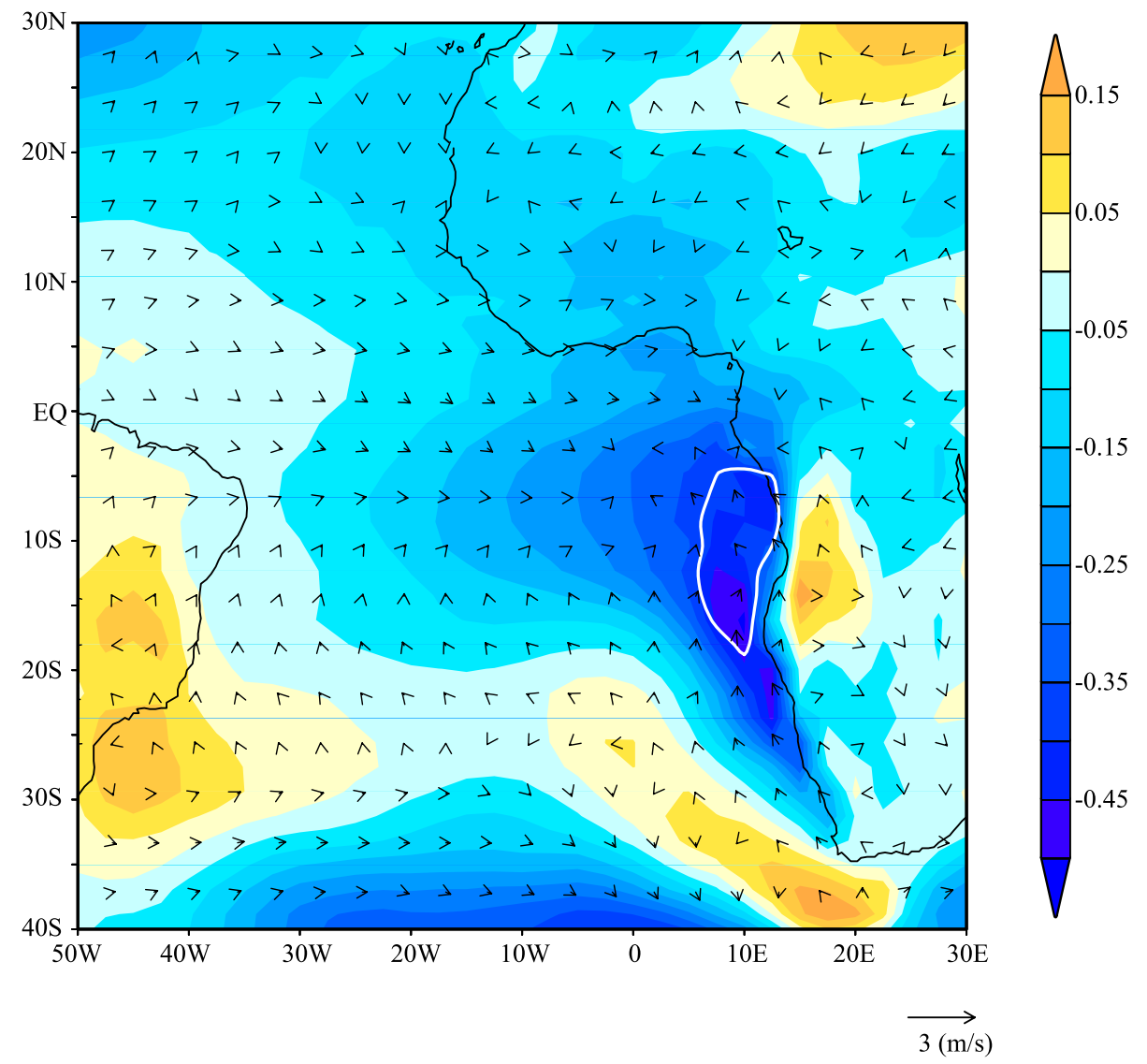

dynamical contribution to these errors there. In the ABFZ, however, the annual mean warm bias is not enhanced by remote wind error: it is almost equal in O-NorESM-TA Wind and $\mathrm{O}-A-C T L$-Wind (Figs. 5,8 ), although seasonally there is a $0.2-0.3{ }^{\circ} \mathrm{C}$ increase in JJA (not shown).
(O-CTL), particularly, in the Gulf of Guinea (Figs. 4, 8). This is consistent with the equatorial westerly wind bias in NorESM that suppresses the development of the ACT in JJA. The subtropical cold biases in O-NorESM-TA_Wind are also slightly enhanced by the NorESM wind errors, suggesting a (b) O-NorESM-TA_WindHeat

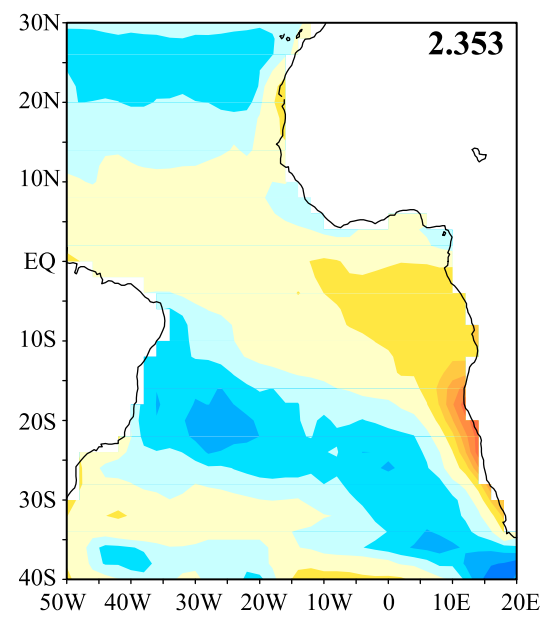

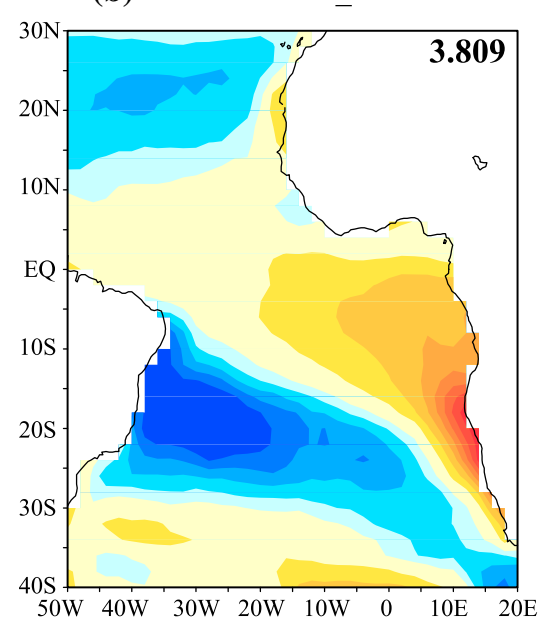

(c) O-NorESM-TA_All

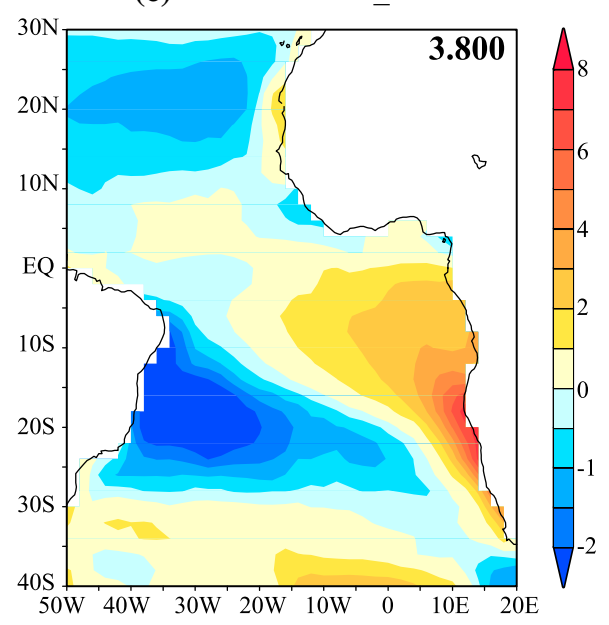

Fig. 8 Climatological bias of annual-mean SST in a O-NorESM-TA_Wind, b O-NorESM-TA_WindHeat, and c O-NorESM-TA_All with respect to HadISST2 for the period $1980-2004$. The RMSEs of SST bias of each experiment $\left(25^{\circ} \mathrm{S}-10^{\circ} \mathrm{S} ; 0^{\circ}-15^{\circ} \mathrm{E}\right)$ are indicated 
To quantify the contribution of turbulent heat fluxes to the SST bias we perform a MICOM experiment (O-NorESMTA_WindHeat) identical to O-NorESM-TA_Wind except that the $10-\mathrm{m}$ temperature and specific humidity biases of NorESM are added when computing turbulent heat fluxes (see Appendix A2). The results show (Figs. 1, 8a, b) that most of the residual NorESM SST bias that is unaccounted for in O-NorESM-TA_Wind can be explained by the additional impact of turbulent heat flux errors. The equatorial SST warm bias extends westward and is enhanced in the Gulf of Guinea and the cold SST biases in the Southern/ Northern Atlantic are also reinforced. The largest difference

(a) Heat flux received ocean

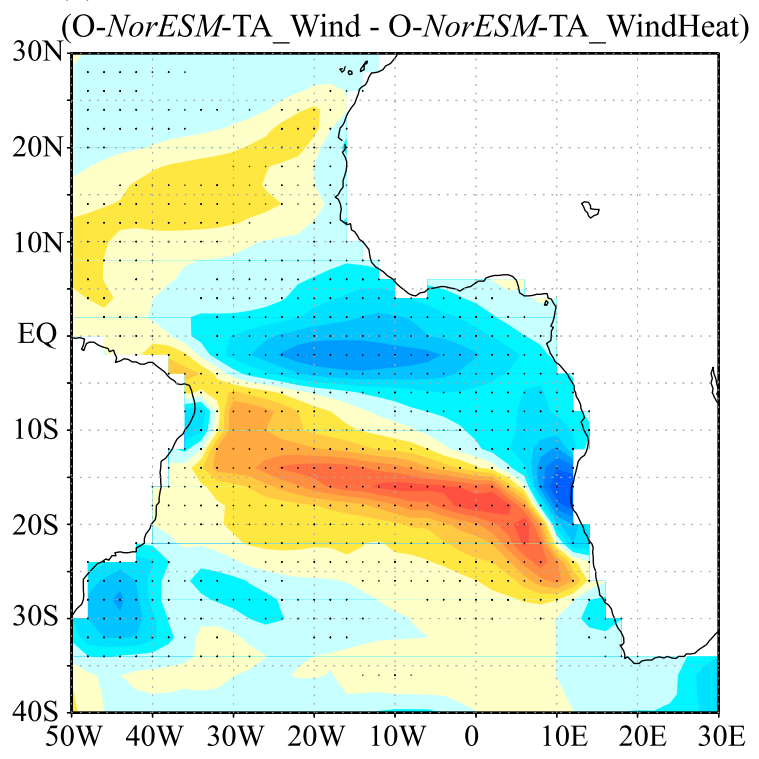

is in the ABFZ, however, where the warm bias is amplified and reaches about $8{ }^{\circ} \mathrm{C}$, matching that in NorESM (see Fig. 1).

In greater details, negative (positive) net surface flux anomalies are located over the equatorial Atlantic and ABFZ (Southern Atlantic) where we have the warm (cold) SST bias in experiments. Thus, O-NorESM-TA_Wind tends to lose more heat fluxes from the ocean surface to the bottom of the atmosphere over the equatorial Atlantic and the ABFZ and vice versa over the southern Atlantic. The heat flux differences mainly result from the latent heat flux (Fig. 9b). In O-NorESM-TA_WindHeat, the COREv2-IAF

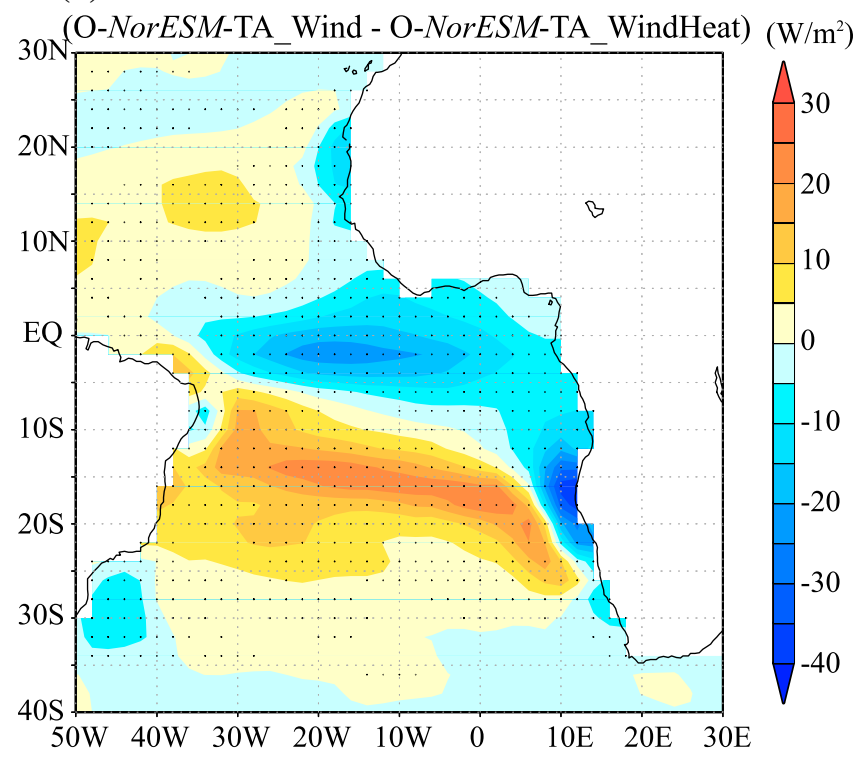

$\left(\mathrm{W} / \mathrm{m}^{2}\right)(\mathbf{c})$ Latent heat flux averaged 10E-12E

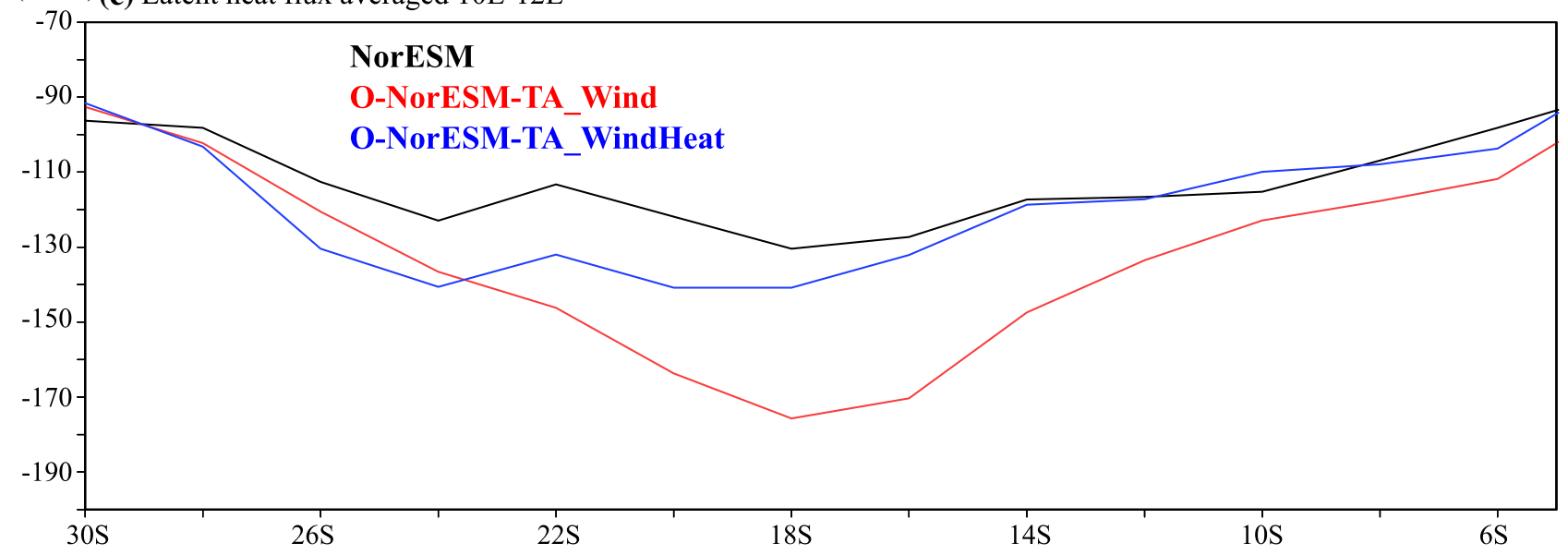

Fig. 9 Climatological difference of annual-mean a heat flux received by the ocean and b latent heat flux between O-NorESM-TA_Wind and O-NorESM-TA_WindHeat. Upward (downward) flux is defined as negative (positive). c Climatology of annual mean latent heat flux simulated by NorESM (black), O-NorESM-TA_Wind (red) and O-NorESM-TA_WindHeat (blue) averaged between 10E and 12E. The black dots on $\mathbf{a}$ and $\mathbf{b}$ denote the differences significant at the 95\% level according to the Student's $t$ test 
protocol implies a form of temperature relaxation that is proportional to the differences between NorESM and CAM4 control (A-CTL; see Appendix A2), which is not entirely realistic and absent in coupled mode. Nevertheless, the same reduction in latent heat flux in the ABFZ compared with O-NorESM-TA_Wind can be also detected in NorESM and its magnitude is roughly identical with that in O-NorESMTA_WindHeat (Fig. 9c).

Consistent with the results from O-NorESM-TA_WindHeat, another MICOM experiment (O-NorESM-TA_All) that in addition includes shortwave radiation bias shows almost unchanged SST bias (Fig. 8c). This indicates that the shortwave radiation errors do not play a major role in causing the SST warm bias in the ABFZ in the annual mean. However, there is a small impact on its seasonality: the warm SST bias is slightly enhanced in JJA (up to $0.4{ }^{\circ} \mathrm{C}$ compared to O-NorESM-TA_WindHeat), while it is suppressed in DJF (to $-0.4{ }^{\circ} \mathrm{C}$ compared to O-NorESM-TA_WindHeat, not shown).

Figure 10 summarizes the contributions to the warm SST bias in the ABFZ as estimated by the standalone model experiments. Firstly, our ocean model, MICOM, has an intrinsic bias of about a half of NorESM full SST bias when driven by COREv2-IAF forcing. CAM4 simulations driven by observed SST have an intrinsic local negative wind stress curl error, which enhances the warm bias through the erroneous southward intrusion of the local Angola Current that contributes to about a quarter of the full SST bias. Another quarter of SST full bias appears to result from to insufficient latent heat flux cooling.

\section{Ocean subsurface structure}

In this section, we consider some ocean subsurface diagnostics to further confirm our conclusions on the causes of the ABFZ SST warm bias. The MICOM control run (O-CTL) reproduces reasonably well the observed mean ocean subsurface temperature along $10^{\circ} \mathrm{E}$ from World Ocean Atlas 13 (WOA13; Fig. 11a, b). However, O-CTL shows a much thicker warm upper-layer than observed, and the temperatures below are colder. Compared to O-CTL, NorESM has a warm anomaly in the surface and cold anomaly in the subsurface between $14-30^{\circ} \mathrm{S}$, indicating a stronger stratification (Fig. 11c). In fact, the ocean mixed layer is shallower in NorESM than in O-CTL (not shown). The thermocline in NorESM (defined by the $17{ }^{\circ} \mathrm{C}$ isotherm) shoals compared to O-CTL, especially, between $26^{\circ} \mathrm{S}$ and $18^{\circ} \mathrm{S}$, broadly matching the region of the negative wind stress curl bias (Fig. 1), and consistent with wind stress curl driven Ekman upwelling. O-A-CTL-Wind shows that adding local wind errors to the COREv2-IAF forcing leads to a similar subsurface temperature structure to NorESM (Fig. 11d). This is consistent with a dynamical origin to the ABFZ SST bias.

Adding remote wind errors (O-NorESM-TA_Wind) leads to a deeper thermocline depth and the warmer subsurface temperature along $10^{\circ} \mathrm{E}$ (Fig. 11e); whereas the mixed-layer depth in O-NorESM-TA_Wind is almost identical with that in O-A-CTL-Wind (not shown). The increase in subsurface ocean temperature is greatest at lower latitude $\left(18^{\circ} \mathrm{S}-6^{\circ} \mathrm{S}\right)$. This is likely because O-NorESM-TA Wind is forced also by the tropical Atlantic errors and the westerly anomaly causes a deepening of the thermocline on the eastern side of the basin and the eastern equatorial Atlantic warm SST bias (Figs. 2, 8b). Despite the enhanced subsurface temperature errors from tropical forcing, the surface errors in the ABFZ are hardly amplified

$(\operatorname{deg} C)$

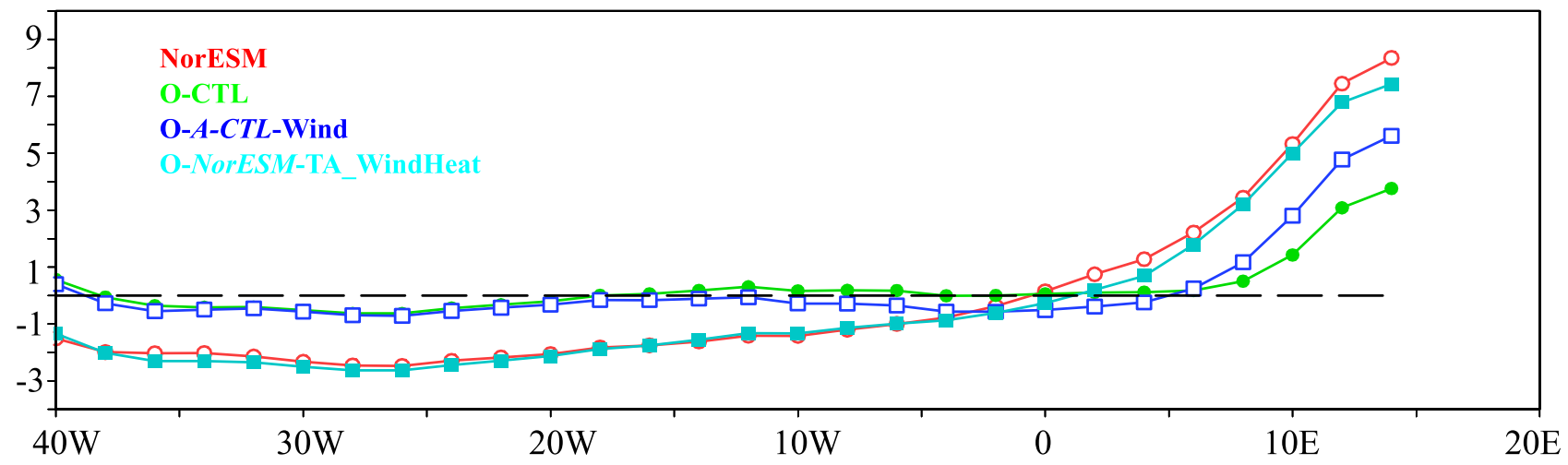

Fig. 10 Longitude section of climatological annual-mean SST bias with respect to the observation of HadISST (19802004) observations for NorESM (red), O-CTL (green), O-A-
CTL-Wind (blue), and O-NorESM-TA_WindHeat (light blue). Each line is averaged between $17^{\circ} \mathrm{S}$ and $22^{\circ} \mathrm{S}$ 

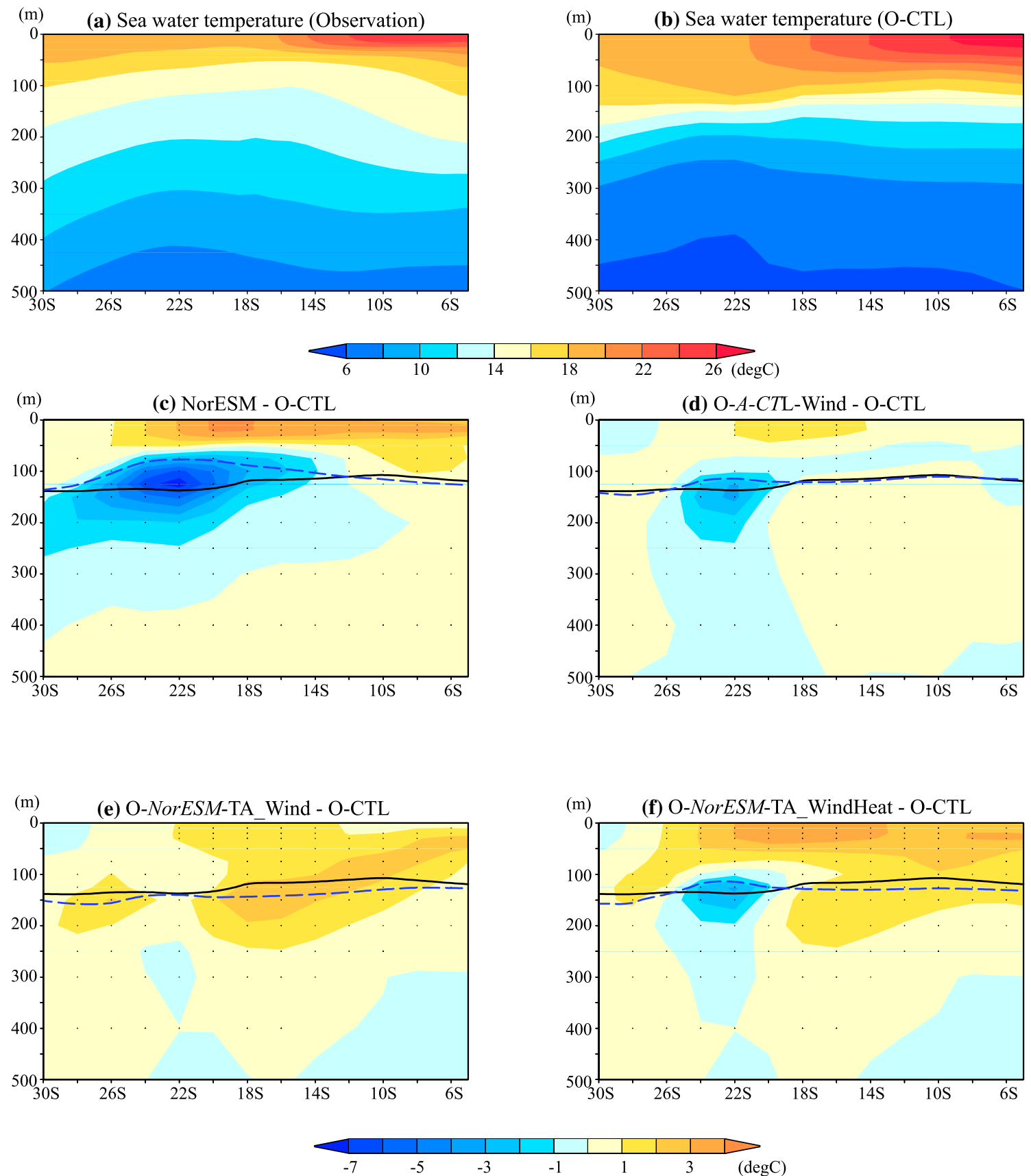

Fig. 11 Depth-latitude section along $10^{\circ} \mathrm{E}$ of climatological annualmean sea water temperature, a World Ocean Atlas (1985-2004) and b O-CTL and the differences of c NorESM, d O-A-CTL-Wind, e O-NorESM-TA_Wind, and f O-NorESM-TA_WindHeat with respect

in O-NorESM-TA_Wind compared to O-A-CTL-Wind. O-NorESM-TA_WindHeat shows that when we accounting for surface turbulent heat fluxes differences related to NorESM biases, the ocean subsurface becomes cooler and the ocean surface becomes warmer (Fig. 11f). This indicates a stronger stratification that qualitatively mimics to O-CTL. The black and blue-dashed lines denote $17{ }^{\circ} \mathrm{C}$ isotherm that is a proxy of thermocline depth for O-CTL and other experiments. The black dots show differences significant at the $95 \%$ level according to the Student's $t$ test

that in the NorESM although with a smaller amplitude. These results support the role of local heat fluxes errors on enhancing the ABFZ SST bias in NorESM, and suggest that local stratification inhibits the impact of remotely forced errors. 


\section{Seasonal cycle of the ABFZ and its bias}

To better understand the causes of the ABFZ SST bias in the coupled model, we now consider the seasonal cycle of the $\mathrm{ABFZ}$ along $10^{\circ} \mathrm{E}$ in the observations, in NorESM, and in the sensitivity experiments (Fig. 12). Observations show that the ABFZ is located between $15^{\circ} \mathrm{S}$ and $18^{\circ} \mathrm{S}$ and its intensity has a clear semi-annual cycle, with two peaks in April and December (Fig. 12a). The intrusion of warm tropical water associated with the locally-enhanced Angola Current has a semi-annual variation, peaking in February and October (Rouault 2012; Fig. S2). The two peaks in the intensity the ABFZ partly reflect the semi-annual variation of the Angola Current. The upwelling season in the Benguela is noticeable in the southern part of the domain from July to October.

In NorESM, the ABFZ is permanently located further south in all months $\left(21^{\circ} \mathrm{S}-23^{\circ} \mathrm{S}\right.$, Fig. $\left.12 \mathrm{~b}\right)$, leading to a persistent warm SST bias that peaks between July and August. Although the intensity of the ABFZ in NorESM is much weaker than observed, the coupled model is able to partly capture the observed seasonal cycle, with a lag of about 1 month. The phase lag is partly consistent with the stronger southward extension of the meridional surface geostrophic current occurring in May and November at $10^{\circ} \mathrm{E}, 15^{\circ} \mathrm{S}$
(Fig. S2). NorESM does not capture the active Benguela upwelling from July to October and there seems to be intense intrusion warm water from lower latitude between February to June (due to the locally-stronger Angola Current associated with the negative wind stress curl error). In particular, the intrusion of the warm water simulated by NorESM is similar to the situation of Benguela Nino events (e.g., Shannon et al. 1986).

The MICOM control run (O-CTL) simulates the seasonal cycle and the position of the ABFZ more realistically: the peak of front intensity during austral summer and autumn is well captured and the Benguela upwelling seems to be more active than in NorESM, although the ABFZ is located (at $18^{\circ} \mathrm{S}$ ) slightly south of its observed position and much more diffuse (Fig. 12c). The addition of local cyclonic wind stress errors (O-A-CTL-Wind) shifts the ABFZ further south to $21^{\circ} \mathrm{S}$ in all seasons, but the seasonal variations in intensity are not strongly affected; only the peak in April seems slightly delayed, closer to that in NorESM (Fig. 12d). As shown in Fig. 5, the local negative wind stress curl errors enhance the Angola Current locally and cause warm tropical water to intrude too far south.

Accounting for turbulent heat flux differences related to NorESM biases (O-NorESM-TA_WindHeat) causes greater differences in the position and seasonality of the (a) HadISST

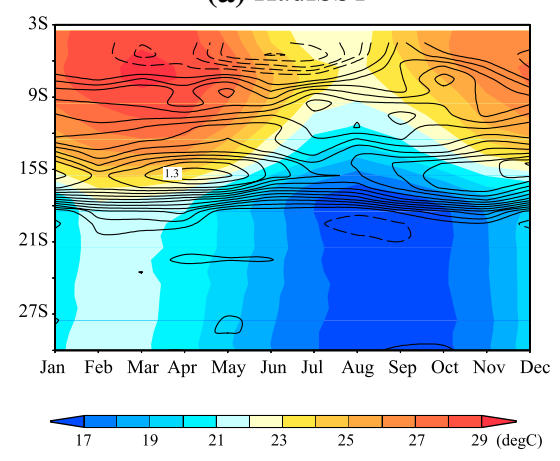

(b) NorESM

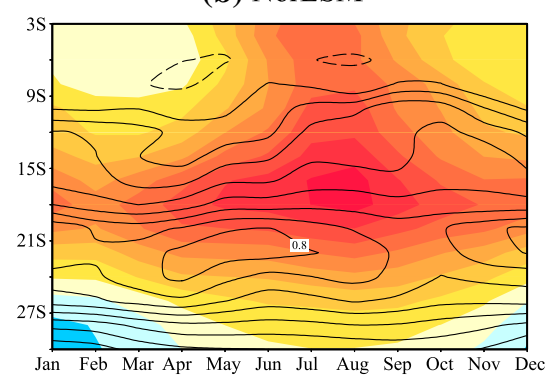

(c) O-CTL

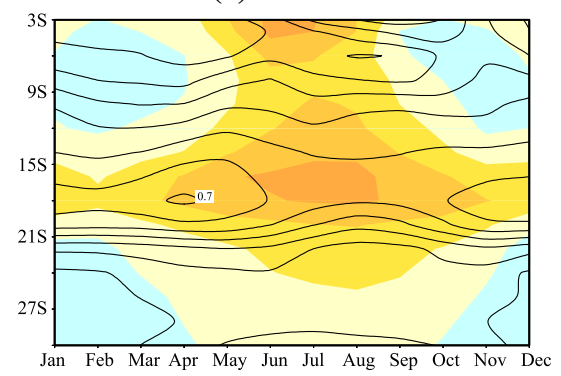

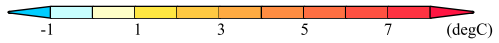

(d) O-A-CTL-Wind

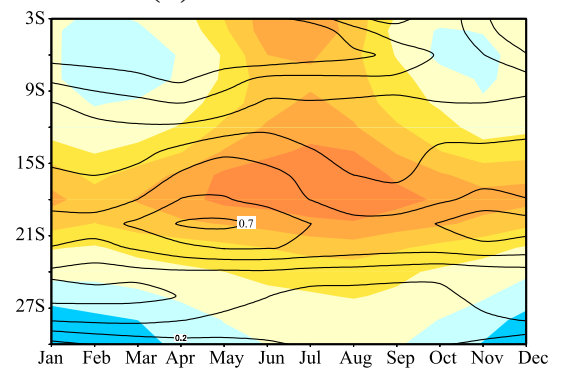

(e) O-NorESM-TA_WindHeat

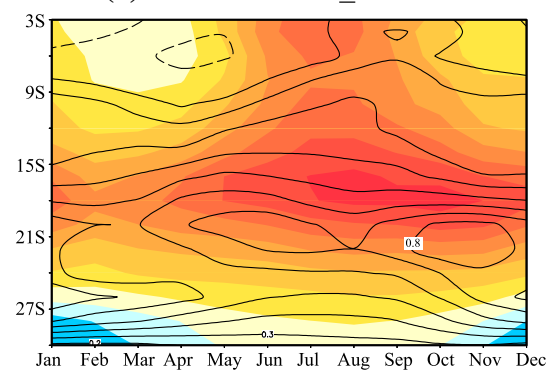

Fig. 12 Climatological annual cycle of observed SST (shaded) and meridional gradient of SST (contours with $0.1{ }^{\circ} \mathrm{C} / 100 \mathrm{~km}$ interval) along $10^{\circ} \mathrm{E}$. b-e The SST bias (shaded) and meridional gradient of SST (contours) along $10^{\circ} \mathrm{E}$ for b NorESM, c O-CTL, d O-A-CTL-
Wind, and e O-NorESM-TA_WindHeat. HadISST observations for the period 1980-2004 are plotted in (a) and used in (b)-(e) to compute model SST biases 
ABFZ, compared to the other MICOM simulations. The maximum of the ABFZ in O-NorESM-TA_WindHeat shifts even further southward between $21^{\circ} \mathrm{S}$ and $24^{\circ} \mathrm{S}$ (Fig. 12e). Furthermore, the cool SST due to the Benguela upwelling seems to be suppressed. This can be explained by the different heat flux forcing compared to O-A-CTL-Wind. In summary, the error in the ABFZ in NorESM shows to first order little seasonality because the front is permanently displaced south. Nevertheless, errors in ocean circulation and upwelling, and surface turbulent fluxes modulate the strength of error.

\section{Discussion and concluding remarks}

We have investigated the causes of the warm SST bias in the southeastern Atlantic Ocean and in the ABFZ in the coupled general-circulation model NorESM (Bentsen et al. 2013). NorESM simulates a large SST warm bias in the ABFZ of up to $8{ }^{\circ} \mathrm{C}$. This warm SST bias is associated with an erroneously strong Angola Current and weak Benguela Current and consequently, the ABFZ is displaced southward. The ocean current errors are attributed to a negative wind stress curl error in the ABFZ.

We analyse several standalone experiments of atmosphere and ocean models and find that our atmospheric model (CAM4) and ocean model (MICOM) possess intrinsic errors similar to those found in NorESM. When run with observed SST boundary conditions, CAM4 produces regional lowpressure anomaly and cyclonic surface wind biases in the ABFZ. MICOM forced following the COREv2-IAF (Large and Yeager 2008) protocol simulates a warm SST bias in the ABFZ that is about a half of NorESM full bias. The warm SST bias in the ABFZ is increased by about $2{ }^{\circ} \mathrm{C}$ (a quarter of NorESM full bias) when the local CAM4 surface wind errors are added to the COREv2-IAF forcing locally. MICOM, despite the coarse $\sim 1^{\circ}$ ocean model resolution, simulates a near surface, coastally trapped Angola Current with similarities to observations, but less intense than observed from mooring data at $11^{\circ} \mathrm{S}, 13^{\circ} \mathrm{E}$ (Kopte et al. 2017). Adding the CAM4 negative wind stress curl bias drives a stronger surface Angola Current in the ABFZ and causes tropical warm water to penetrate farther south, consistent with Xu et al. (2014). Furthermore, the magnitudes of the biases in surface ocean mechanical quantities (ocean current, wind stress curl and SSH) are roughly equal to those in NorESM. Local feedbacks between ocean and atmosphere circulation do not further enhance the ABFZ SST bias because the CAM4 wind stress curl response to the local SST error is relatively weak.

The rest of the warm SST bias is explained by biases in the latent heat flux forcing. In the experiments considering only surface wind errors, latent heat flux tends to damp the
SST errors because of the fixed surface air temperature and humidity used in the bulk formula. The ocean surface fluxes are enhanced under the fixed forcing of temperature and specific humidity. On the other hand, when the temperature and specific humidity errors (O-NorESM-TA_WindHeat) are included, the latent heat flux cooling is suppressed and the remaining SST errors in the ABFZ can be explained. The reduced latent heat flux is similar to that seen in the coupled NorESM simulation. In particular, the warming and moistening of the atmosphere over the warm SSTs in the simulations (NorESM and O-NorESM-TA_WindHeat) suppresses the ocean heat flux release. Thus, the intrinsic atmospheric mechanical errors still act and the heat due to them can remain in the ocean.

Our experiments also show that the impact from remote equatorial wind errors seem not to contribute actively to the warm SST bias in the ABFZ in NorESM, although the ocean subsurface seems to be affected (Fig. 10). When the MICOM is forced by the NorESM surface winds over the whole of the tropical Atlantic Ocean (O-NorESMTA_Wind), the subsurface temperature from the $\sim 6^{\circ} \mathrm{S}$ to the ABFZ is warmer than that in simulations with observational based winds over the equatorial Atlantic (O-CTL and $\mathrm{O}-A-C T L$-Wind). However, the ABFZ SST warm bias is not amplified by the remotely forced subsurface temperature errors. This is probably because the thermocline in the MICOM control run is much deeper than the observed, limiting the impact of thermocline variations at the ocean surface. Nevertheless, the impact of ocean subsurface biases deserves investigation.

The warm SST bias also affects the seasonal cycle of the ABFZ. In NorESM, the ABFZ is located southward year around, while the seasonal variations in its intensity lag the observations by about 1 month. Moreover, the amplitude of the seasonal cycle of the ABFZ intensity is relatively weaker in NorESM and the MICOM experiments compared to the observation. These discrepancies can be partly caused by the seasonal cycle of the geostrophic current in the model that is not represented well because of the negative wind stress curl error in the ABFZ. Additionally, heat flux errors (O-NorESM-TA_WindHeat) broadens and strengthens slightly the ABFZ, making it more consistent with that in NorESM. This result indicates that the ocean heat flux also plays a certain role for frontogenesis/frontolysis of the ABFZ in addition to the oceanic current. A deeper understanding of these features requires a diagnostic study of the frontogenesis function (e.g., Kazmin and Rienecker 1996; Jacobs et al. 2014; Giordani and Caniaux 2014), but is beyond this study.

Through a series of standalone experiments we evaluate the separate dynamical and thermodynamical, and local and remote contributions to the warm ABFZ SST bias. Quantitatively, the main contributors causing the annual-mean 
warm SST bias in the ABFZ simulated by NorESM are as follows: (1) $50 \%$ is attributed to MICOM intrinsic errors, (2) $25 \%$ is generated by CAM4 intrinsic error of wind stress curl, and (3) $25 \%$ is induced by the reduced atmospheric heat flux damping in the coupled system. Note our estimates of the intrinsic model component errors are dependent on the quality of the observations used to force the models. For (1), the intrinsic error is also found equal strength in another CORE-forced experiment with higher resolution. This suggests that the MICOM errors are more related to the CORE-forcing, which cannot perfectly capture the local wind stress field over the ABFZ. Colberg and Reason (2006) have shown that the location and intensity of the ABFZ depends highly on the local wind stress. Additionally, a short run with blended QuikSCAT (Mears et al. 1999) winds shows that MICOM errors were reduced by about $1.5^{\circ} \mathrm{C}$ in the ABFZ compared to MICOM control run (not shown). Small et al. (2015) concluded that both of higher resolution models of atmosphere and ocean are desirable to simulate a realistic ABFZ. We hope that this study can direct future studies to reduce model systematic errors in the tropical Atlantic.

Acknowledgements The authors would express their appreciation to two anonymous reviewers for their helpful comments. The authors would like to appreciate Prof. C.R. Mechoso in University of California, Los Angelsm Prof. W. Cabos in University of Alcalá, and Prof. A. Timmerman in University of Hawaii for their constructive discussions. We utilized the version of 2012Ra of MATLAB software package provided by The MathWorks, Inc., (http://www.mathworks.com) and Grid Analysis and Display System (GrADS, http://www.iges.org/ grads/) to compute each dataset and create figures. The research leading o these results received funding from the EU FP7/2007-2013 under Grant agreement to no. 603521 (EU-PREFACE). Computing resources were provided by NTur (nn9039k, ns9039k).

Open Access This article is distributed under the terms of the Creative Commons Attribution 4.0 International License (http:// creativecommons.org/licenses/by/4.0/), which permits unrestricted use, distribution, and reproduction in any medium, provided you give appropriate credit to the original author(s) and the source, provide a link to the Creative Commons license, and indicate if changes were made.

\section{Appendix}

\section{A.1 Blending methodology}

The prescribed forcing data is decomposed into climatological and transient components as follows,

$F_{O}=\overline{F_{O}}+F_{O}^{\prime}$

where, overbar (prime) denotes the climatological (transient) components and subscript $O$ means observational forcing.
The climatological part of forcing data is blended with climatology of model output as follows,

$F_{B}=\varepsilon \overline{F_{M}}+(1-\varepsilon) \overline{F_{O}}+F_{O}^{\prime}$

where, subscripts of $B$ and $M$ denote blended forcing data and model output, respectively. $\varepsilon$ is a blending coefficient defined as,

$\varepsilon=\exp \left(\frac{\left(X_{r e f 1}-X_{t}\right)^{2}}{X_{a}}-\frac{\left(Y_{r e f 1}-Y_{j}\right)^{2}}{Y_{a}}\right)$ for the ABFZ,

and

$\varepsilon=\exp \left(\frac{\left(X_{r e f 2}-X_{t}\right)^{2}}{X_{b}}-\frac{\left(Y_{r e f 2}-Y_{j}\right)^{2}}{Y_{b}}\right)$

for the southern-tropical Atlantic.

Each blending coefficient is centred at $\left(X_{r e f 1}, Y_{r e f 1}\right)$ and $\left(X_{\text {ref } 2}, Y_{\text {ref } 2}\right)$. Numerators indicate the zonal and meridional distances from the centre at each grid point. Denominators defined the scale for the blending coefficient horizontal distribution.

Figure 13 shows distributions of each blending coefficient.

\section{A.2 Adding methodology}

We employ an alternative methodology for adding temperature and specific humidity anomalies to the COREv2IAF forcing for the O-NorESM-TA_WindHeat experiment because NorESM does not have $10 \mathrm{~m}$ temperature and specific humidity. Figure 14 shows the climatological annualmean difference of the temperature and specific humidity at the lowest model level (at $992 \mathrm{hPa}$ ) between NorESM and A-CTL. Basically, the anomalies are consistent with the warm SST biases in NorESM. The ratio of anomalies with A-CTL climatology is defined as,

$\alpha=\frac{\bar{T}_{N o r E S M}-\bar{T}_{A 1}}{\bar{T}_{A 1}}, \beta=\frac{\bar{q}_{N o r E S M}-\bar{q}_{A 1}}{\bar{q}_{A 1}}$,

where over-bar denotes the climatology and subscript the experiment. This ratio provides an estimate of the coupled model error as compared to the uncoupled atmospheric model. We assume that the errors in the NorESM 10 m quantities have the same ratio and thus to assess the contribution of these errors to the simulation of SST we add an anomaly proportional to this ratio to the climatological component of COREv2-IAF,

$T_{O 5}-T^{\prime}+(1+\varepsilon \alpha) \bar{T}, q_{O 5}=q_{O 5}-q^{\prime}(1+\varepsilon \beta) \bar{q}$ 
Fig. 13 Horizontal distribution of each blending coefficient (a) Blending coefficient for the ABFZ

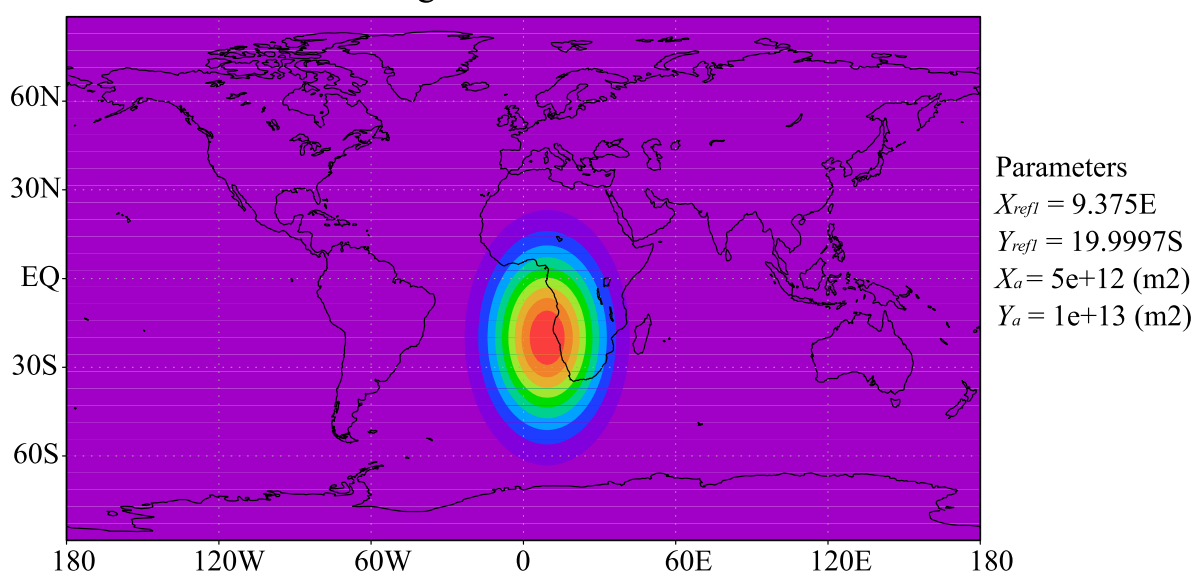

(b) Blending coefficient for the Atlantic
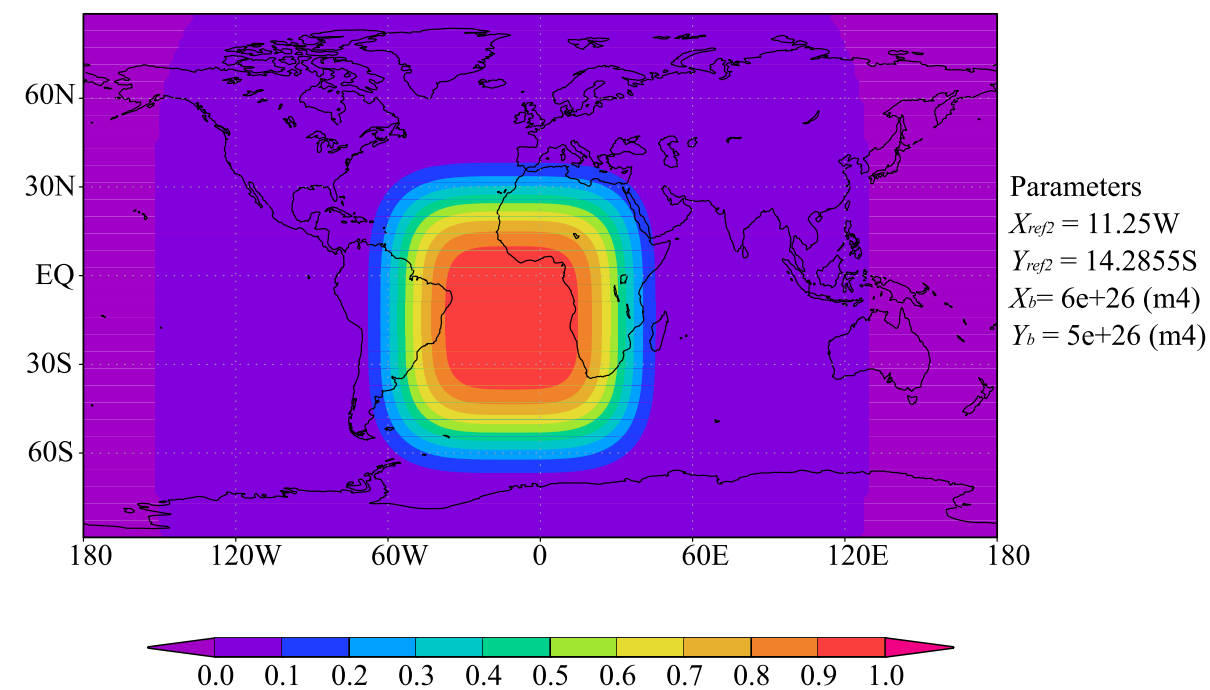

(a) Temperature

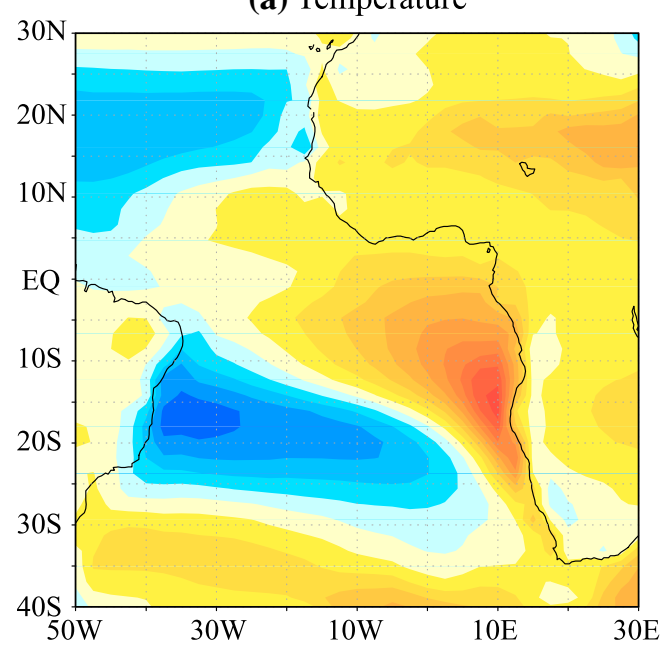

(b) Specific humidity

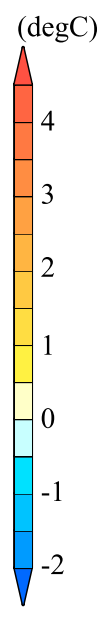

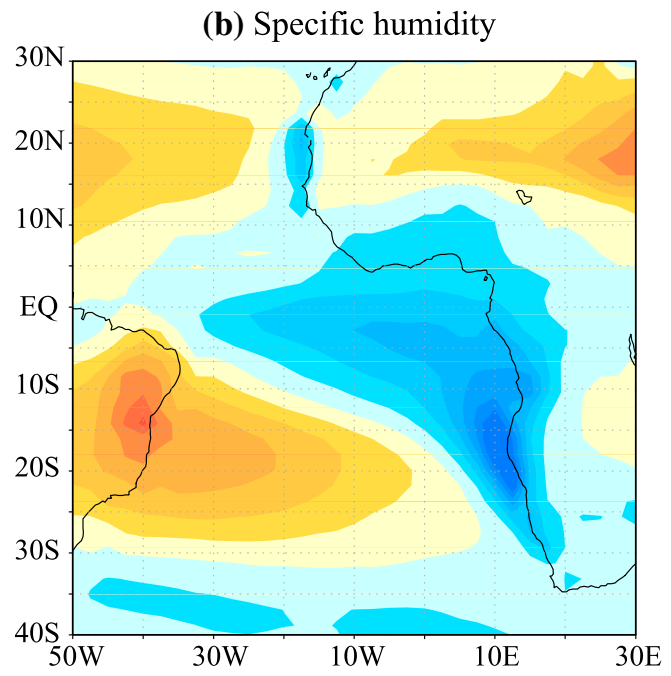

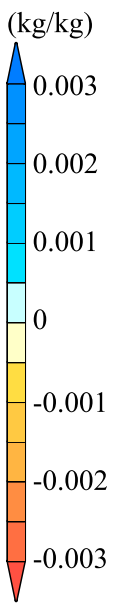

Fig. 14 Climatological annual-mean difference of a temperature and b specific humidity at the model's lowest-level between NorESM and A1 
Here, the coefficient of is defined as Eq. A4 and over-bar (prime) denotes the climatological (transient) component for COREv2-IAF.

\section{References}

Auel H, Verheye HM (2007) Hypoxia tolerance in the copepod Calanoides carinatus and the effect of an intermediate oxygen minimum layer on copecod vertical distribution in the northern Bengulea Current upwelling system and the Angola-Benguela Front. J Exp Mar Bio Eco 352:234-243. doi:10.1026/j.jembe.2007.07.020

Bentsen M, I.Bethke JB, Debernard T, Iversen A, Kirkevåg Ø., Seland H, Drange C, Roelandt IA, Seierstad C, Hoose, Kristjánsson JE (2013) The Norwegian Earth System Model, NorESM1-M-Part 1: description and basic evaluation of the physical climate. Geosci Model Dev 6:687-720. doi:10.5159/ gmd-6-687-2013

Biasutti M, Sobel AH, Kushnir Y (2006) AGCM Precipitation Biases in the Tropical Atlantic. J Climate 19:935-958

Bilo TC, de Silveira ICA, Belo WC, de Castro BM, Piola AR (2014) Methods of estimating the velocities of the Brazil Current in the pre-salt reservoir area off southeast Brazil (23(a similar to) S -26(a similar to) S). Ocean Dyn 64:1431-1446. doi:10.1007/ s10236-014-0761-2

Bjerknes J (1969) Atmospheric teleconnections from the equatorial Pacific. Mon Wea Rev 97:163-172

Bleck R, Rooth C, Hu D, Smith LT (1992) Salinity-driven thermocline transients in a wind - and thermohaline - forced isopycnic coordinate model of the North Atlantic. J Phys Oceanogr 22:1486-1505

Breugem W-P, Chang P, Jang CJ, Mignot J, Hazeleger W (2008) Barrier layers and tropical Atlantic SST biases in coupled GCMs. Tellus A 60A:885-897. doi:10.1111/j.1600-0870.2008.00343.x

Cabos W, Stein DV, Pinto JG, Fink AH, Koldunov NV, Alvarez F, Izquierdo A, Keenlyside N, Jacob D, 2016. The South Atlantic Anticyclone as a key player for the representation of the tropical Atlantic climate in coupled climate model. Clim Dyn. doi:10.1007/s00382-016-3319-9

Chavez FP, Messié M (2009) A comparison of eastern boundary upwelling ecosystem. Prog Oceanogr 83(1-4):80-96. http://www. sciencedirect.com/science/article/pii/S0079661109000998

Colberg F, Reason CJC (2006) A model study of the Angola Benguela Frontal Zone: Sensitivity to atmospheric forcing. Geophys Res Lett 33:L19608. doi:10.1029/2006GL027463

Colberg F, Reason CJC (2007) A model investigation of internal variability in the Angola Benguela Forntal Zone. J Geophys Res 112:C07008. doi:10.1029/2006JC003920

Counillon F, Bethke I, Keenlyside NS, Bentsen M, Bertino L, Zheng F (2014) Seaosnal-to-decadal predictions with the ensemble Kalman filter and the Norwegian Earth System Model: a twin experiment. Tellus A 66:21074. doi:10.3402/tellusa.v66.21074

Dee DP, Uppala SM, Simmons AJ, Berrisford P, Poli P, Kobayashi S, Andrae U, Balmaseda MA, Balsamo G, Bauer P, Bechtold P, Beljaars A. C. M., van de Berg L, Bidlot J, Bormann N, Delsol C, Dragani R, Fuentes M, Geer AJ, Haimberger L, Healy SB, Hersbach H, Hólm EV, Isaksen L, Kållberg P, Köhler M, Matricardi M, McNally AP, Monge-Sanz BM, Morcrette J-J, Park B-K, Peubey C, de Rosnay P, Tavolato C, Thépaut J-N, Vitart F (2011) The ERA-Interim reanalysis: configuration and performance of the data assimilation system. QJR Meteorol Soc 137:553-597. doi:10.1002/qj. 828

Deppenmeier A-L, Haarsma RJ, Hazeleger W (2016) The Bjerknes feedbacks in the tropical Atlantic in CMIP5 models. Clim Dyn. doi:10.1007/s00382-016-2992-z
Ding H, Keenlyside N, Latif M, Park W, Wahl S (2015) The impact of mean state errors on equatorial Atlantic interannual variability in a climate model. J Geophys Res 120:1133-1151. doi:10.1002 /2014JC010384

Druyan LM, Fulakeza M (2014) The impact of the Atlantic cold tongue on West African monsoon onset in regional model simulations for 1998-2002. Int J Climatol 35:275-287. doi:10.1002/joc.3980

Fennel W, Junler T, Schmidt M, Mohrholz V (2012) Response of the Benguela upwelling systems to spatial variations in the wind stress. Cont Shelf Res 45:65-77. doi:10.1016/j.csr.2012.06.004

Florenchie P, Lutjeharms JE, Reason CJC, Masson S, Rouault M, 2003. The source of Benguela Ninos in the South Atlantic Ocean. Geophys Res Lett. doi:10.1029/2003GL017172

Giordani H, Caniaux G (2014) Lagrangian sources of frontogenesis in the equatorial Atlantic front. Clim Dyn 43:3147-3162. doi:10.1007/s00382-014-2293-3

Goubanova K, Illig S, Machu E, Garcon V, Dewitte B (2013) SST subseasonal variability in the central Benguela upwelling system as inferred from satellite observation (1999-2009). J Geophys Res 118:4092-4110. doi:10.1002/jgrc.20287

Grodsky SA, Carton JA, Nigam S, Okumura Y (2012) Tropical Atlantic Biases in CCSM4. J Climate 25:3684-3701. doi:10.1175/ JCLI-D-11-00315.1

Harlaß J, Latif M, Park W (2015) Improving climate model simulation of tropical Atlantic sea surface temperature: The importance of enhanced vertical atmosphere model resolution. Geopys Res Lett 42:2401-2408. doi:10.1002/2015GL063310

Hazeleger W, Haarsma RJ (2005) Sensitivity of tropical Atlantic climate to mixing in a coupled ocean-atmosphere model. Clim Dyn 25:387-399. doi:10.1007/s00382-005-0047-y

Hirst AC, Hastenrath S (1983) Atmopshere-ocean mechanisms of climate anomalies in the Angola-Tropical Atlantic sector. J Phys Oceanogr 13:1146-1157. doi:10.1175/1520-0485(1983)013<1146:AOMOCA > 2.0.CO;2

Hu Z-Z, Huang B, Pegion K (2008) Low cloud errors over the southeastern Atlantic in the NCEP CFS and their association with lower tropospheric stability and air-sea interaction. J Geophys Res. doi :10.1029/2007JD009514

Hu Z-Z, Huang B, Hou Y-T et al (2010) Sensitivity of tropical climate to low-level clouds in the NCEP climate forecast system. Clim Dyn 36:1795-1811. doi:10.1007/s00382-010-0797-z

Huang B (2004) Remotely forced variability in the tropical Atlantic Ocean. ClimDyn 23:133-152

Jacobs GA, Richman JG, Doyle JD, Spence PL, Bartels BP, Barron CN, Helber RW, Bub FL (2014) Simulating conditional deterministic predictability within ocean frontogenesis. Ocean Model 78:1-16

Junker T, Schmidt M, Mohrholz V (2015) The relation of wind stress curl and medirional transport in the Benguela upwelling system. $\mathrm{J}$ Mar Syst 143(2015):1-6. doi:10.1016/j.marsys.2014.10.006

Kazmin AS, Rienecker MM (1996) Variability and frontogenesis in the large-scale oceanic frontal zones. J Geophys Res 101(C1):907-921

Keenlyside N, Latif M (2007) Understanding equatorial Atlantic interannual variability. J Climate 20:131-142

Klein SA, Hartmann DL (1993) The seasonal cycle of low stratiform clouds. J Climate 6:1587-1606

Kopte R, Brandt P, Dengler M et al (2017) The Angola Current: Flow and hydrographic characteristics as observed at $11^{\circ} \mathrm{S}$. J Geophys Res Ocean. doi:10.1002/2016JC012374

Koshiro T, Shiotani M (2014) Relationship between Low Stratiform Cloud Amount and Estimated Inversion Strength in the Lower Troposphere over the Global Ocean in Term of Cloud Types. J Meteor Soc Jpn 92:107-120. doi:10.2151/jmsj-2014-107

Large WG, Danabasoglu G (2006) Attribution and impacts of upperocean biases in CCSM3. J Clim 19(11):2325-2346 
Large WG, Yeager SG (2008) The global climatology of an interannual varying air-sea flux data set. Clim Dyn 33:341-364. doi:10.1007/ s00382-008-0441-3

Li G, Xie S-P (2012) Origins of tropical-wide SST biases in CMIP multi-model ensembles. Geo Phys Lett 39:L22703. doi:10.1029 /2012GL053777

Locarnini RA, Mishonov AV, Antonov JI, Boyer TP, Garcia HE, Baranova OK, Zweng MM, Paver CR, Reagan JR, Johnson DR, Hamilton M, Seidov D (2013) World Ocean Atlas 2013, Volume 1: temperature. Levitus S (ed), A. Mishonov Technical Ed.; NOAA Atlas NESDIS 73

Lübbecke JF, Böning CW, Keenlyside NS, Xie S-P (2010) On the connection between Benguela and equatorial Atlantic Ninos and the role of South Atlantic Anticyclone. J Geophys Res 115:C09015. doi:10.1029/2009JC005964

Mears CA, Smith DK, Wentz FJ (1999) Development of a Rain Flag for QuikScat. Technical report number 121999, Remote Sensing Systems. Santa Rosa, CA

Mechoso CR, Losada T, Koseki S, Mohino-Harris E, Keenlyside N, Canstaño-Tierno A, Rondríguez-Fonseca B, Myers TA, Toniazzo $\mathrm{T}$ (2016) Can reducing the income energy flux over the Southern Ocean in a CGCM improve its simulation of tropical climate? Geophys Res Lett. doi:10.1002/2016GL071150

Miyasaka T, Nakamura H (2010) Structure and mechanisms of the Southern hemisphere summertime subtropical anticyclone. J Climate 23:2115-2130. doi:10.1175/2009JCLI3008.1

Mohrholz V, Schmidt M, Lutjeharms JRE, John H-CH (2004) Spacetime behavior of the Angola-Benguela Frontal Zone during the Benguela Nino of April 1999. Int J Remote Sens 25:1337-1400. doi:10.1080/01431160310001592265

Nicholson SE, Entekhabi D (1987) Rainfall variability in equatorial and Southern Africa: relationships with sea surface temperatures along the southwestern Coast of Africa. J Climate Appl Meteor 26:561-578. doi:10.1175/1520-0450(1987)026<0561:RVIEAS $>2.0 . \mathrm{CO} ; 2$

Nnamchi HC, Li J, Kucharski F, Kang IS, Keenlyside NS, Chang P, Farneti R (2015) Thermodynamic controls of the Atlantic Niño. Nature Commun 6:8895

Okumura Y, Xie S-P (2004) Interaction of the Atlantic Equatorial Cold Tongue and the African Monsoon. J Climate 17:3589-3602

Patricola CM, Chang P (2016) Structure and dynamics of the Benguela low-level coastal jet. Clim Dyn 0:0. doi:10.1007/ s00382-016-3479-7

Patricola CM, Li M, Xu Z, Chang P, Saravanan R, Hsieh J-S (2012) An investigation of tropical Atlantic bias in a high-resolution coupled regional climate model. Clim Dyn 39:2243-2463

Pfeifroth U, Hollmann R, Ahrens B (2012) Cloud Cover Diurnal Cycles in Satellite Data and Regional Climate Model Simulations. Meteorol Z 21:551-560. doi:10.1127/0941-2948/2012/0423

Reynolds RW, Rayner NA, Smith TM, DC: Stokes, Wang W (2002) An improved in situ and satellite SST analysis for climate

Richter I (2015) Climate model biases in the eastern tropical oceans: causes, impacts and ways forward. WIREs Clim Change 6:345358. doi: $10.1002 /$ wcc. 338

Richter I, Xie S-P (2008) On the origin of equatorial Atlantic biases in coupled general circulation model. Clim Dyn 31:587-598. doi: 10.1007/s00382-008-0364-Z

Richter I, Behara SK, Masumoto Y, Taguchi B, Komori N, Yamagata T (2010) On the triggering of Benguela Ninos: remote equatorial versus local influences. Geophys Res Lett 37:L20604. doi:10.10 29/2010GL044461
Richter I, Xie S-P, Wittenberg AT, Masumoto Y (2012) Tropical Atlantic biases and their relation to surface wind stress and terrestrial precipitation. Clim Dyn 38:985-1001. doi:10.1007/ s00382-011-1038-9.

Richter I, Xie S-P, Behara SK, Doi T, Masumoto Y (2014) Equatorial Atlantic variability and its relation to mean state biases in CMIP5. Clim Dyn 42:171-188. doi:10.1007/s00382-012-1624-5

Rouault M (2012) Bi-annual intrusion of tropical water in the northern Benguela upwelling. Geophys Res Lett 39:L12606. doi:10.1029 /2012GL052099

Rouault M, Florenchie P, Fauchereau N, Reason CJC (2003) South east tropical Atlantic warm events and southern African rainfall. Geophys Res Lett 30:8009. doi:10.1029/2002GL014840

Shannon LV, Boyd AJ, Brundrit GB, Taunton-Clark J (1986) On the existence of an El-Nino type phenomenon in the Benguela system. J Mar Res 44:495-520. doi:10.1357/002224086788403105

Small RJ, Bacmeister J, Bailey D, Baker A, Bishop S, Bryan F, Caron J, Dennis J, Gent P, Hsu HM, Jochum M, Lawrence D, Muñoz E, diNezio P, Scheitlin T, Tomas R, Tribbia J, Tseng YH, Vertenstein M (2014) A new synoptic scale resolving global climate simulation using the Community Earth System Model. J Adv Model Earth Syst 6(4):1065-1094

Small RJ, Curchister E, Hedstrom K et al (2015) The Benguela upwelling system: quantifying the sensitivity to resolution and coastal wind representation in a global climate model. J Clim 28:9409-9432. doi:10.1175/JCLI-D-15-0192.1

Steele M, Morley R, Ermold W (2001) A global ocean hydrography with a high quality arctic oocean. J Climate 14:2079-2087

Taylor KE, Stouffer RJ, Meehl GA (2012) An overview of CMIP5 and the experiment design. Bull Am Meteorol Soc 93:485-498

Tichner HA, Ravner NA (2014) The met Office Hadley Centre sea ice and sea surface temperature data set, version2: 1 . Sea ice concentrations. J Geophys Res 119:2864-2889

Toniazzo T, Woolnough S (2014) Development of warm SST errors in the southern tropical Atlantic in CMIP5 decadal hindcasts. Clim Dyn 43:2889-2913. doi:10.1007/s00382-013-1691-2

Tozuka T, Doi T, Miyasaka T, Keenlyside N, Yamagata T (2011) Key factors in simulating the equatorial Atlantic zonal sea surface temperature gradient in a coupled general circulation model. J Geophys Res 116 (C6)

Veitch JA, Florenchie P, Shillington FA (2006) Seasonal and interannual fluctuations of the Angola-Benguela Frontal Zone (ABFZ) using $4.5 \mathrm{~km}$ resolution satellite imagery from 1982 to 1999 . Int J Remote Sens 27:987-998. doi:10.1080/01431160500127914

Vertenstein M, Craig T, Middleton A, Feddema D, Fischer C (2012) CESM 1.0.3 users guide. http://www.cesm.ucar.edu/models/ cesm1.0/cesm/cesm_doc_1_0_4/ug.pdf

Vizy EK, Cook KH (2014) Capturing the Atlantic cold tongue and coastal upwelling in an intermediate-level ocean model coupled to a regional climate model. Clim Dyn 42:345-366. doi:10.1007/ s00382-013-1807-8

Wahl S, Latif M, Park W, Keenlyside N (2011) On the tropical Atlantic SST warm bias in the Kiel Climate Model. Clim Dyn 36:891-906. doi:10.1007/s00382-009-0690-9

Xu Z, Chang P, Richter I, Kim W, Tang G (2014) Diagnosing southeast tropical Atlantic SST and ocean circulation biases in the CMIP5 ensemble. Clim Dyn 43:3123-3145. doi:10.1007/ s00382-014-2247-9

Zermeno D, Zhang C (2013) Possible Root Causes of the Surface Westerly Biases over the Equatorial Atlantic in Global Climate Models. J Climate 26:8154-8168 